Article

\title{
Towards Sustainable Digital Innovation of SMEs from the Developing Countries in the Context of the Digital Economy and Frugal Environment
}

\author{
Zahid Yousaf ${ }^{1, * \mathbb{D}}$, Magdalena Radulescu ${ }^{2,3, *}$, Crenguta Ileana Sinisi ${ }^{4}\left(\mathbb{D}\right.$, Luminita Serbanescu $^{2}$ \\ and Loredana Maria Păunescu ${ }^{5}$ \\ 1 Higher Education Department, Government College of Management Sciences of Manshera, \\ Mansehra 23100, Pakistan \\ 2 Department of Finance, Accounting and Economics, University of Pitesti, Str. Targu din Vale, no.1, \\ 110040 Pitesti, Romania; luminita.serbanescu@upit.ro \\ 3 Doctoral School, University “Lucian Blaga" of Sibiu, Bd. Victoriei, no.10, 550024 Sibiu, Romania \\ 4 Department of Management and Business Administration, University of Pitesti, Str. Targu din Vale, no.1, \\ 110040 Pitesti, Romania; crengutaileana77@gmail.com \\ 5 Department of Cybernetics, Economic Informatics, Finance and Accounting, \\ Petroleum-Gas University of Ploiesti, 100680 Ploiesti, Romania; loredana.paunescu@yahoo.com \\ * Correspondence: muhammadzahid.yusuf@gmail.com (Z.Y.); magdalena.radulescu@upit.ro (M.R.)
}

Citation: Yousaf, Z.; Radulescu, M.; Sinisi, C.I.; Serbanescu, L.; Păunescu, L.M. Towards Sustainable Digital Innovation of SMEs from the Developing Countries in the Context of the Digital Economy and Frugal Environment. Sustainability 2021, 13, 5715. https://doi.org/10.3390/ su13105715

Academic Editors: Eglantina Hysa, Félix Puime Guillén, Alba Kruja, Mirela Panait and Ahsan Akbar

Received: 26 April 2021

Accepted: 18 May 2021

Published: 19 May 2021

Publisher's Note: MDPI stays neutral with regard to jurisdictional claims in published maps and institutional affiliations.

Copyright: (c) 2021 by the authors. Licensee MDPI, Basel, Switzerland. This article is an open access article distributed under the terms and conditions of the Creative Commons Attribution (CC BY) license (https:// creativecommons.org/licenses/by/ $4.0 /)$.

\begin{abstract}
This study aims to explore the direct impact of the digital orientation, Internet of Things (IoT) and digital platforms on the sustainable digital innovation in the context of the digital economy and frugal environment. This study also investigated the mediating role of the digital platforms in these relations. The study was based on the quantitative research design and data were collected from the 397 CEOs and managing directors of Small and Medium Enterprises in Pakistan. Correlation and structural equation modeling approaches were applied for the analysis and testing of the hypotheses. Results revealed that the digital orientation, IoT and digital platform are major antecedents of the sustainable digital innovation. Results also show that the digital platforms mediate between both digital orientation-sustainable digital innovation link and IoT-sustainable digital innovation link. The rapid pace of change in the technology has forced the business organizations to think out of box and align their operational mechanism accordingly. The need for the sustainable digital innovation is a major need of the current decade for meeting the increasing demands of the society in a sustainable way. Organizations, especially SMEs, should be able to deal with these challenges and rapid technological transformations through cost effective frugal business models. The frugal innovation is an important element of sustainable digital innovation enables SMEs to reduce resources usage and waste and to enhance sustainable economic activities. In this way, they can develop and gain advantages in this highly competitive digital environment. This is the first study showing the bright harmony of the digital orientation, IoT and digital platforms for achieving the sustainable digital innovation in the rapid evolving digital economy.
\end{abstract}

Keywords: sustainable digital innovation; digital economy; digital orientation; Internet of Things (IoT); digital platform; SMEs; developing economies

\section{Introduction}

The emergence of digital innovation and technologies are able to drive social and economic development [1]. Digital innovation has shifted the traditional business economy into the digitalized one [2] and digital transformation of the economy is highly based upon big data and the advanced technologies [3]. Digital innovation is not a specific feature of the software organizations anymore and even the first most valuable business organizations in the world belong to the digital sectors [4]. 
Due to the complexity and technological dynamism, it is challenging to achieve the digital innovation in the digital economy [5]. All types of businesses and more specifically the Small and Medium Enterprises (SMEs) face these challenges. This technological progress can maximize the opportunities for SMEs [6]. The changes induced by the digital technologies in the organizations' business model represent a real challenge for all organizations in general and for SMEs more specifically [7]. If the digital transformations represent an opportunity or a challenge for SMEs, they depend on how these SMEs will strategically tackle it [8]. SMEs operating in the digital economy critically need the digital innovation for facing important challenges and for improving their technical expertise [9]. SMEs represent key participants on the market [10], especially during the structural change periods in the digital economy [11], thus it is important to analyze how they can manage in the digital economy in a sustainable way.

Digital innovation is referring to a product, process or business model that is new or requires significant changes and it is enabled by IT [12]. Sustainable digital innovation supports the digitalization process of the economy in a green, long-lasting and organic way. Thus, it serves the need of a sustainable future. The regular digital innovation addresses performances, costs, technology and attractiveness to customers and business, while the sustainable one also addresses to the environmental and social factors. Sustainable digital innovation tries to create value for all the stakeholders involved in the production and distribution process, it is inspired by nature, not only by technology, it reduces resources waste and targets the societal goals, not only the commercial and business goals.

Digitalization determines a significant shift in the business framework and it is a result of the 4th Industrial Revolution. The industrial revolution is a natural process due to technological achievements that took place in social and economic systems [13]. The 4th Industrial Revolution is characterized by the industrial implementation of inventions such as the Internet of Things, artificial intelligence, advanced robots, autonomous vehicles, cloud computing, big data, augmented/simulated reality, 3D printing, blockchain, etc. [14]. Its main innovations will reshape the economy structure towards service sectors, while the goods that can mainly benefit from the 4th Industrial Revolution will be those whose costs have so far been high in transport, logistics, information, regulation, and transaction [15].

Previous researchers highlighted various factors which predict digital innovation like: transformation and institutional perspective [16], digital innovation strategy [17], division of innovative labor and digital control [18], strategic transformation [19], digital workplace [20], big data [21], information technology [22], agility [23], organizational culture [24], innovation standards [25], organizational readiness [26] and organizational learning [27]. Still, they have overlooked some important and influential antecedents of sustainable digital innovation analyzed together, like, digital platform, digital orientation and Internet of Things (IoT), so far [28,29]. Hence, a comprehensive research study is required to fill this research gap. The current study overcomes this research gap and proves that SMEs can achieve the sustainable digital innovation through the nexus of the digital orientation, IoT and digital platforms. The current study explores how SMEs can reach the sustainable digital innovation in the digital economy, in the frugal framework specific to the developing markets.

The digital innovation is a powerful combination of the digital technology and digital management expertise for innovating the business processes and for reaching some creative solutions [30,31]. In the digital economy, SMEs mostly perform their operational mechanisms through adapting new technology, new software or digital platforms which support their transformation from analog-to-digital processes [32]. At the same time, digital orientation and IoT help to boost the process of the sustainable digital innovation in the digital economy prospect, in the frugal framework specific to the developing markets. Digital innovation differs among the used digital platforms according to their specific features, architecture and management practices; thus, the organizations can customize the digital platforms according to their specific needs and participate in creating the digital innovation [4]. Digital technology (such as IoT, social and cloud computing, big data 
analytics) empowers the digital platforms and digital innovation [33]. The organizations can manage a major rapid sustainable digital innovation by adequately adapting and using of the digital technologies and digital platforms and by accumulating dynamic digital capabilities and embracing an overall digital orientation.

The digital orientation refers to the premeditated strategic placement of an enterprise to get the benefits of the bright opportunities smoked by the digital technologies [34]. The previous researchers have explored the multiple aspects of the digital orientation including its role in SME performance [8], intangible value drivers [35] and structuring and compensating top management teams [34]. The exact way an organization can benefit from a digital-oriented strategy is still very scarcely presented in the existing literature. So far, no comprehensive research has been carried out in order to explore the association of the digital orientation with the sustainable digital innovation [36]. Digital orientation allows organizations to rapidly adapt to customer demands [37] and to elaborate innovative products and services [38]. This represents a great advantage when customer needs rapidly develop [39], just like in the digital innovation case [40]. The digital orientation grants incentives for SMEs to adopt digital technologies, to overcome their rigid boundaries, to achieve digital innovation and to reach companies development and growth [8]. However, these effects differ among different types and sizes of SMEs, economic sectors and among countries. All the existing empirical studies have focused so far on case-studies.

The current study also highlights IoT as a major source of the sustainable digital innovation. IoT refers to the advancement of the technology in order to communicate and get connected constantly all around the world using internet and devices [41]. The major aim of IoT is to simplify processes in all domains, to increase the efficiency of systems and processes in order to achieve mainly the sustainability goals without negatively affecting the commercial viability and goals of the organisations and finally to improve life quality for all. IoT technologies are the basis of the 4th Industrial Revolution due to their relevance for the sustainable digital innovations and for the benefits gained by the population [42]. Internet of Things and digital platforms display a significant impact on the organizations' efficiency, costs and productivity. The use of the new technologies better meets the customers' demand, supports a better understanding of the customers' behavior, adjusts the existing products and services, innovates new ones, even at lower more affordable prices and, overall, supports the sustainable digital innovation.

Digital technologies impact all the social life areas, but they mainly determine the transformation of entrepreneurial and business models in different industries. The development of the digital platforms has significantly influenced the digital innovation in many sectors, such as health care (Patients Like Me), financial industry (PayPal), transportation (Uber), hospitality (Airbnb, TripAdvisor), education (Google Classroom) and software (Apple iOS, Google Android). Users' access to the Internet and to different products and services through digital platforms constitute the foundation and existence of these services and have transformed the classical business models into the new era of digitization [43].

Organizations that have used the digital platforms have achieved important growth in digital innovation. Thus, the digital platforms became a significant business model and a source for major economic growth for many domains [44]. Many recent studies, such as [45], have analyzed how digital platforms have reshaped business and organizational models and transformed the whole economy frame. One of the major outcomes of the digital technology (digital orientation and IoT) is represented by the digital platforms which play a pivotal role in reshaping the way that SMEs can gain a competitive advantage.

Some studies have been conducted regarding the digital platforms in relation with the ecosystem [46], the dynamic and integrative capabilities [47], the performance [32], the adoption of platform strategies [48], the impact of digital platforms on health and society [49] and the online transactions [50]. The information about the role of the digital platforms for achieving the sustainable digital innovation is very limited [51]. The direct role of the digital platforms has also been studied by several researchers [46], but the mediating role has not been analyzed so far. The digital platforms support cutting the 
transaction costs [52], the technological development of new products and services by adequate governance structures [53] and offer new solutions for the business issues [54]. The role of the digital platforms in the sustainable digital innovations turned from classical products and services innovation to the innovation of the entire business models.

However, this research has studied the mediating role of the digital platforms. This study assumes that the digital platforms act as a driver of the digital orientation and IoT to reach the sustainable digital innovation in the digital economy in the frugal framework of the developing countries. There is a dire need among the SMEs to adapt further their investments in the digital innovation because the SMEs are in a continuous struggle to survive in a highly competitive market through the sustainable digital innovation [55]. To respond to this competitive pressure, the SMEs adopt the digital technologies and IoT for implementing their business strategy [56]. New software, devices and network standards have enabled the emergence of some new features.

This research aims to investigate both the direct and mediated impact of the digital orientation and IoT on the sustainable digital innovation in case of the developing markets. This research has also shown that the digital orientation and IoT significantly affect the digital platform. This study developed a sustainable digital innovation model through digital orientation, IoT and digital platforms. The mediating role of the digital platform has also been explored in this research. This study has tested the digital platforms as a mediator in both links between digital orientation-sustainable digital innovation and IoT-sustainable digital innovation.

SMEs display different features against large companies and this can also be seen in their digital transformation process. Thus, a deeper insight for analyzing the digital transformation and digital innovation of SMEs is necessary [57]. Some previous researchers have demonstrated the role of adopting digital technologies in triggering the chances in the business process of SMEs that play a crucial role in value creation of the countries or in achieving digital innovation for SMEs [58], but few studies have analyzed how digital transformation can re-design the whole business model of an organization [59]. Adopting and implementing digital transformation also demands specific resources, structures and skills that SMEs do not always possess and there is scarce knowledge on that issue. A more in-depth analysis is needed for finding an adequate resource configuration and business model that SMEs need for gaining advantages as a result of their technological development and what capabilities do SMEs need to develop for achieving sustainable digital innovation [60]. There is a deep need to understand how SMEs perform in a strategic way [61], because it has been observed that especially SMEs from developing countries pay less attention toward their strategic goals [62].

Many small firms develop products and services to fulfill the needs of the low-income customers from the developing countries, thereby contributing to sustainability [63]. Developing economies are considered adequate for low-cost innovation, it is called frugal innovation [64]. Frugal innovation is considered a catalyst for the sustainable innovation and for achieving the sustainable development in the developing economies $[65,66]$. Designing sustainable products and services for the low-income consumers in the developing countries is a major challenge for businesses [67]. Frugal innovation overcomes the resource constraints in the developing markets and supports the implementation of new business models for finding affordable solutions [68]. Frugal innovation is a new paradigm aiming to produce cheaper goods, through local cheaper inputs. As it saves materials and energy in the producing process, it contributes to a better use of the resources. Frugal innovation displays the ability to recycle the used components. It represents the engine of the technological change therefore it also supports the transition towards a greener economy and, in this sense, it is considered a big step towards achieving sustainability [69]. New technologies support frugal innovation because they allow cost cut, multiple use and recycle of these digital resources. Basu et al. [70] consider frugal innovation to be a significant way to create sustainable innovation and solutions for businesses. 
The importance of building such a model for organizations in order to reach digital innovation is important in the sustainability frame. The current pandemic has demonstrated the role of digitalization and digital transformation and accelerated the digital transformation across all sectors. Without the digital transformation of the businesses, the economic and environmental challenges of the future cannot be addressed in a sustainable way [71]. Digital innovation has proven its major role for achieving long-term economic growth, reducing unemployment, improving life quality, granting a broader access to the public services and reducing the cost in many sectors of the economy [60]. Some recent papers have demonstrated the perspective of sustainability when the digital transformation takes place in the organization frame [72] and some authors have demonstrated the moderating role of digital transformation between digital readiness, digital technology, digital business models and a sustainable digital innovation [71]. An analysis of the World Economic Forum showed that $84 \%$ of existing IoT can address and support the achievements of the UN's Sustainable Development Goals (SDGs). Digitalization creates new opportunities to achieve Sustainable Development Goals. It is estimated that industrial IoT will provide major economic value to the world economy until 2030 and this can rise even more if consumer and public sector IoT (smart-city-related projects) are considered [72].

Sustainable businesses are those who aim both self-interests but also collective ones, targeting social, economic and ecological goals [73]. The convergence of the sustainability goals and use of the digital technologies became important both in the private and public sectors lately [74], but there is a research gap in the academic area on this specific topic.

Digital sustainability can be defined as the organizational activities that aim to address to the sustainable development goals through a creative use of the digital technologies [67]. For tackling sustainability goals, the organizations should aim digital innovation in a more complex way, namely by developing the whole business models focused on this specific purpose. The organizations can play a major role in how the global industrial system will manage the SDGs grand challenges [75].

Therefore, being and acting "digital" is a major condition for achieving the UN's SDGs [76]. By implementing new digital business models, the supply chains are enabled to cut the unnecessary consumptions, as well as to digitally transform the business model for reaching a sustainable value creation and for strengthening the relation with their customers. Businesses can develop without negatively impacting on environment [75,77].

This study was based on the quantitative research methods and standardized pretested questionnaires were used for data collection. Correlation and structural equation modeling (SEM) approaches were utilized for the analysis and testing of the hypotheses. Indirect effect for mediation analysis was conducted through Process, Sobel test. The objectives of study were achieved by conducting the analysis on the basis of live experience of 397 CEOs and MDs.

This paper has been arranged in the following structure: Section 2 is comprised of the theoretical background on the sustainable digital innovation, digital platform, digital orientation and IoT. Section 3 presents the research methodology. Next, results are presented, and the main finding, managerial implications, theoretical implications and future research suggestions have been discussed.

\section{Literature Review}

\subsection{Digital Orientation and Sustainable Digital Innovation}

The digital orientation is the adoption of the digital practices by utilizing advanced technologies like mobile applications, digitized processes, social networks and so on [8]. The digital orientation refers to an organization's strategic orientation towards using the advanced technologies and implementing the digitized processes in running its business in order to increase its value creation. This strategic orientation plays a supportive role for innovation considering the proper use of proactive innovation, market insight and candidness to new-fangled ideas [35]. For increasing the value business creation, the organizational strategy of the companies matters as much as the used technology. Thus, 
a more in-depth analysis is necessary to see how the business models can be re-designed to respond successfully to the digital transformation for achieving sustainable digital innovation. This way, the created value can increase, the organization's performance can rise and the company can gain competitive advantages. This can be beneficial for the whole economy, as some previous studies have demonstrated so far [78]. Adopting digital technologies and practices by the companies can support their performance in a sustainable way and can respond to some fundamental questions about how the companies contribute to society well-being and what tools they need for responding to the demands of the society [78,79]. A digital-oriented business can avail of the value creation and persuade business to be an effective part of the digital economy [79]. The digital orientation suits business in this changing environment and ensures that businesses can only survive by adopting the latest and most innovative methods [34]. To differentiate the business from the competitors in order to benefit of the competitive advantage, the businesses are focused on managing the digital innovation by using the digital orientation [80]. The analysis of the role of the digital capabilities and internal resources through the digital orientation can provide an in-depth understanding of the digital innovation potential [81]. If the firms are capable of using the digital activities in their processes, they can potentially achieve the digital innovation according to the new technological ways [82].

Organizations need to adapt to the digital technologies and digital platforms, eventually adapting the products, work environments and the entire business context. This could be supported by designing new digital business models. The organizations displaying a high orientation towards optimization, customer interaction and utilization of the digital technologies are more susceptible to achieve a sustainable digital innovation and digital transformation [71]. Sustainable digital innovation is not only a result of the link between digital technologies and digital platforms, but is also influenced by the firms' digital orientation to speed-up the digital innovation. Thus, digital orientation is an enabler for achieving sustainable digital innovation. Activities have to be fitted to every individual business model so that the digitalization can be sustainable [83].

The existing studies empirically validated three major approaches of the innovation: the Schumpeterian view, the Marshallian view and the technology pull view. According to the Schumpeterian view, the entrepreneurs cause the disturbance of the market equilibrium on a continuous basis and contribute to innovation. According to the Marshallian view, the innovation system is the original notion of the industrial districts, while the technology push view states that the innovation adoption of the firm can be determined by the capability of the firm to adopt the new and innovative technology. The digital technology is the most contemporary form of technology that can push the SMEs to adopt innovation by the digital inputs [84]. The SMEs need to adopt the digital orientation for speeding up the process of the sustainable digital innovation and this requires a huge investment [85]. The digitally-oriented firms are willing to bear the cost and risks for achieving the targets of the sustainable digital innovation and support the transformation of the traditional innovation process into the digital innovation [86]. Hence, the digital orientation is a major antecedent of the sustainable digital innovation. The technology acceptance model reflects that adopting attitude affects the innovation adoption decision [87]. If the organization has the capability to adopt the innovation through different means, it can achieve a high-level productivity from this [6]. From this model, it can be summarized that if the firm can adopt the digital technology, it can make its digital innovation productive [82]. Based on the above argument, it is justified to establish a positive link between the digital orientation and the sustainable digital innovation. Therefore, it leads to the following hypothesis:

Hypothesis 1 (H1). The digital orientation has a positive relationship with the sustainable digital innovation. 


\subsection{Internet of Things and Sustainable Digital Innovation}

Information and operational technology play a significant role in changing the society, the economy, and industries worldwide. It plays four major roles in entrepreneurial operations: as a facilitator, as a mediator and as an outcome; it redesigns and becomes the business model itself. Business models consider the technological change as an opportunity from the business value side. Entrepreneurs search for business model that determine value creation and incorporating the new technologies for achieving sustainable innovation into their businesses. The Internet of Things, big data analytics and artificial intelligence, leads to the adoption of new technologies into the business model in a sustainable way, because the scarcity of the available resources [88].

Some well-known examples of high impact businesses (Facebook, Amazon, Google) have encouraged entrepreneurs to consider that Internet supported business ideas [89].

The advancement of the technology has provided an opportunity to communicate and get connected constantly all around the world with the use of the internet and devices connected to it [90]. These developments in the field of the technology and communication are the Internet of Things (IoT). Every device that is connected to the internet can be an example of the technological wonder and can assist the businesses in the digital economy [91]. The development and advancement of the internet have extended the scope of IT drastically and leads towards the digital innovation. Internet of Things (IoT) bring together so many devices and the results consist of "smart" houses or cities, transportation systems, electricity networks, that will develop economic activities by cutting down the transaction costs [92] and will increase wellbeing of the population. In this way, digital technologies significantly enable the sustainable digital innovation, their effects and results depending on the aim and framework [30].

IoT is involved in every task and activity of the business and influences the operational mechanism. The digital innovation rises through the constant communication and information sharing across borders and among organizations through network connectivity provided by IoT [93]. The information sharing offered by IoT generates the new ideas of doing business gathered from all over the world [94]. The business models that are successfully adapted in some other country can be utilized by gathering knowledge through IoT [90]. A large number of businesses are conducting new ways of reaching their customers or for marketing purposes by using the digital media [95]. These innovative methods of performance of business activities are possible through IoT [82]. The information availability on the internet can support the businesses to implement some new and innovative solutions to the old problems [96]. The Internet-related information and devices allow businesses to develop a new strategy in the old business context leading to the digital innovation [97]. New software and platforms that are the outcomes of IoT are available to the businesses to innovate the old processes [98].

These implications of IoT have been overlooked by previous researchers and there is hardly any evidence about the IoT-digital innovation link so far [99]. Both digital orientation and IoT can determine sustainable digital innovation but this stance is meager at best and hence we have linked these factors: digital orientation and IoT with sustainable digital innovation through digital platform.

Hence, we argue that IoT is a very important factor to enhance the sustainable digital innovation in the digital economy. The socio-economic growth and development of the digital economy are based on the advancement and growth of the IoT-based digital innovation [82]. Therefore, based on this, it is justified to establish that IoT positively affects the sustainable digital innovation in all sizes of business, generally, and in SMEs, specifically. Therefore, the following hypothesis is derived:

Hypothesis 2 (H2). Internet of Things has a positive impact on the sustainable digital innovation. 


\subsection{Digital Orientation and Digital Platform}

The digital platforms include online businesses that regulate the commercial communication between two different parties for mutual benefits [32]. The digital platforms have become very important in the digital economy for the success of the businesses [100]. However, the literature has mostly discussed the outcomes of the digital platforms that are derived from the business. Less attention is given to the capabilities and resources upon which the success or failure of the digital platforms depends on. This study highlights that the digital platforms are initiated through the digital orientation. The firm's culture plays a very significant role in the adoption of the digital platforms. If the firm has the digital orientation, then it will support the transformation of its traditional business activities into the digitalized ones [101]. Adopting the digital orientation for business processes can take place at a large scale if the managerial decision supports it. The digital orientation helps to show that more assets are required to be invested in the development and advancement of the increasingly digital platforms to get benefits from it up to its full potential [102]. The readiness of the management to invest in purchasing and implementing the digital technology in the business organization allows the business to benefit of the online digital platforms for the businesses [103]. The digital orientation shows that the firms should be ready to transform their traditional ways of business processes and methodologies into the digital platforms. As it has been discussed above, the firms that are digitally-oriented firms are more inclined toward the adaption of the digital platforms. Therefore, based on it, the following hypothesis is developed:

Hypothesis 3 (H3). Digital orientation has a positive relationship with digital platforms.

\subsection{Internet of Things and Digital Platform}

IoT has extended the productivity and functions of connecting people and organizations through different platforms such as social network service, email, live conferences and other online information sharing and feedback to a large extent [41]. The amount of information sharing and production by the connected devices is also increasing rapidly with the growth of technology and an increase of the number of devices used in this context [102]. IoT has very wide dimensions that include environmental, social and economic impacts that contribute to the growth and sustainability of the digital economy [93]. IoT not only provides communication and connection among millions of devices across the world, but it also provides new opportunities, service paradigms, architectures and new capabilities as well. Online platforms for instance are the most frequently used outcomes of the IoT [99]. The effects of the IoT-based network also influence the digital platforms; as things are growing, they become more influential and valuable to the people. IoT strategy of the platform can be analyzed by the success of connection, data flow, information, knowledge, and attractiveness. The IoT provides an opportunity to develop network globally that connects the things, data and people and create a digital platform [85]. This development provides the capability to the smart devices that are connected through the internet to transmit and share the data and information. IoT enables the services that require connectivity and intelligence regarding analytics and information management on the online platforms [98]. IoT-based mobile devices, things and cloud use the technology for the data transmission boost the development of the digital platforms. Everyone can create and share the content and information using the services of cloud-based platforms and infrastructures that provide access to the global users [41].

The most significant application areas of IoT are related to the industrial organizations where most implemented projects are [104]. The IoT is responsible for the digital transformations of the organizations. IoT speeds up the process of the business involvement in the digital platforms through the internet devices and technological advancements, mobile applications and social network. 
Users have to be taught how to operate on the digital platform to capture value. By shaping the online customer-centric market, the ability of users to achieve value from interactions increases. Therefore, the simplicity of the digital platforms is crucial [89].

Therefore, this study argues that the digital platforms majorly depend on IoT. The things connected with networks maintain the online identity and global connection, which are requirements of the digital platform. IoT-based developed digital platforms are a globally approachable network. These digital platforms are conjunctions of the consumers, users, and things, who contribute to develop businesses, create content and participate in the business transactions online. Based on the above discussion it is justified to establish the argument that the IoT has a direct influence on the digital platforms. Therefore, it leads to the following hypothesis:

Hypothesis 4 (H4). Internet of Things is positively related to the digital platforms.

\subsection{Digital Platform and Sustainable Digital Innovation}

In a changing and competitive environment, one of the crucial determinants is innovation. The ability to achieve the innovation targets and objectives of the organization with digital technology is referred to as digital innovation [47]. Digital technology platforms currently support the innovation of the most products, processes or services within and across the organizations; thus, the digital innovation can be noticed at a large number of firms [105].

The digital platforms offer an online platform to communicate with other organizations that may be business partners, competitors, suppliers or consumers [32]. The digital platforms provide the opportunity to the business to enhance its performance using digital platforms and technological advancements [106]. The interaction between the client and the supplier, or any other parties that are involved in the commercial or business activities by using an online platform is known as a digital platform [107] and their major role in the economy was best emphasized during the current pandemic. Digital platforms gather together the customers, partners and developers and create large markets with significant scale economies and efficiency. They enable cooperation between organizations from many domains that can generate innovation of new products and services. The innovation phenomenon stresses that the digital platforms support innovation and the digital transformation of the organizations.

Digital technologies have generated tools such as digital crowdfunding platforms, social media, 3D printers and digital imaging processors that reduce the barriers for inventions and enable innovation [108]. Increasing number of the entrepreneurial projects using digital crowdfunding platforms for financing reasons determines the development of these platforms [109].

Li et al. [110] presented the transformation of SMEs in a digital ecosystem. This paper described how SMEs have transformed from local to successful cross-border e-commerce players on the digital platforms. "This took place through dynamic managerial capability, organization capability, and strategic changes. The platforms motivate SMEs, providing training on the use of the platform, providing social networking and mutual learning among SMEs, building tools to overcome trading barriers, and motivating SMEs for a strategic transformation".

Facing the digital economy scenarios, the digital platforms are developing and advancing with the advancement in the technology, because this advancement allows the digital innovation. The digital innovation is rooted through the production of the new and latest technologies and majorly based on digital platforms [95]. The digital platforms allow people and firms to get connected through the digital technology and offer the newest digitalized innovation. The sharing of the new ideas and information has also increased and become easy through the digital platforms. This generates the availability of every kind of information and knowledge on the digital platforms [100]. The digital innovation is responsible for bringing the innovation and advancement through the digital platforms. 
The digital innovation is based on the digital platforms as this helps to grant the opportunities of the innovation and new ideas for businesses that are now mostly based on by using the services of the digital platforms. The digital platforms provide the opportunities for businesses to get connected with their potential customers more effectively and efficiently in the newest ways. The digital platforms like Google search engine and other products and services of Google continuously derive digital innovation in order to create more opportunities and productivity for the businesses as well as for individuals [36]. The digital platforms have become the hub of the new business ideas and advertisements across the world [95]. The digital platforms develop technology, institutions and processes using $24 / 7$ connections which turns to the digital innovation.

Achieving resource optimization for sustainable businesses can be reached using the digital technologies, that represent the pillar of the sustainable digital innovations in digital platforms and environments [111]. These digital innovations determine organizational digital transformation through digital technologies and new digital business models, which leads to sustainable implications for many business issues [112].

All the above-stated arguments about the digital platform in perspective of the sustainable digital innovation show that the digital platforms play a significant role in bringing sustainable digital innovation into the business. Therefore, the following hypothesis is derived:

Hypothesis $\mathbf{5}$ (H5). Digital platform is positively related to the sustainable digital innovation.

\subsection{Digital Platform as the Mediator between Digital Orientation and Sustainable Digital Innovation}

The platform age is dominant in this era because of the development of powerful information and communication technologies that have decreased the cost and increased the reach of connecting platform sides, but the entrepreneurship research has ignored the role of the digital technologies in entrepreneurship [113].

This study argues that the digital platforms act as a mediator between the digital orientation and the sustainable digital innovation. Digital orientation leads towards the development of the digital platform for attaining the sustainable digital innovation. The previous studies have presented that the digital orientation predicts the digital platforms [32]. The digital platform provide opportunity to stay connected with top rated firms and can provide a competitive advantage for the businesses to develop the newest technology and creativity in the long run [55]. The digital platforms contribute as a driver for the digital orientation to achieve the sustainable digital innovation. The inclination of the digitally-oriented firms is toward the adoption of the digital technology for its processes (innovation); therefore, they do this through the online media and digital platforms. The willingness and desire of the firms to innovate their processes in a sustainable way can be fulfilled by the applications and information provided by the digital platforms. The digital orientation enables the firms to built-up their web-based business capabilities to go online and develop digital platforms for offering the latest products and services in a digitized innovative way [102].

Therefore, it is argued that the digital orientation initiates the process of the developing digital platform which in turn enhances the sustainable digital innovation.

Hypothesis 6 (H6). Digital platform mediates the relationship between the digital orientation and the sustainable digital innovation.

\subsection{Digital Platform as a Mediator between the Internet of Things and Sustainable Digital Innovation}

IoT brings benefits for both businesses and individuals in the form of developing the connections with the latest technology and its applications with the continuous innovation [41]. Similarly, the creation of the digital platform majorly depends on IoT. This 
research argues that the digital platforms meditate the IoT and sustainable digital innovation link. Different firms and organizations are taking advantage of IoT for achieving the digital platforms through the latest technology and advanced means of communication [32]. These digital platforms help to collect relevant data, information and knowledge to increase the efficiency of all functions of businesses for achieving the digital innovation [103]. The IoT has offered a wide variety of platforms that are present online to perform various functions of the business related to the digital innovation. These digital platforms are helping the businesses to gather the information for bringing the sustainable innovation. These platforms have also offered a wide range of innovative models for doing business in a sustainable way. By offering a wide range of business digital platform opportunities, IoT is deriving sustainable innovation into the business. By linking the IoT for bringing the sustainable digital innovation, the digital platforms may represent a strong connection bridge $[99,100]$. Therefore, based on it, the following hypothesis is derived:

Hypothesis 7 (H7). Digital platform mediates between the Internet of Things and the sustainable digital innovation.

\subsection{Theoretical Framework}

The theoretical underpinning of this study is linked with two major theories, i.e., (1) Theory of Innovation and (2) dynamic capability theory DCT.

Coenen and Lopez [114] reported that Theory of Innovation is based on three major elements, i.e., (1) Sectoral System, (2) Technological System and (3) Socio-Technical System. This study expanded the domain of these three dimensions with the respect of sustainable digital innovation. The Sectoral System highlights the directions sector-based synergies to improve innovation and performance, hence it is related to the sustainable digital innovation. Similarly, Technological System is advancement in technology using the latest knowledge and skills to enhance overall innovation. Finally, Socio-Technical System means radical innovations and transitional innovation based on technology and this innovation is in the best interest of society. The second basis of our theoretical framework is based on dynamic capability theory (DCT) that refers to firms' skills to be flexible and innovative for achieving sustainable performance [115]. It is timely adjustments in a firm's strategies and processes to adopt innovative methods in order to sustain its performance. Hence, sustainable digital innovation is the main concern for firms operating in the current dynamic world. Figure 1 show the theoretical framework of this study.

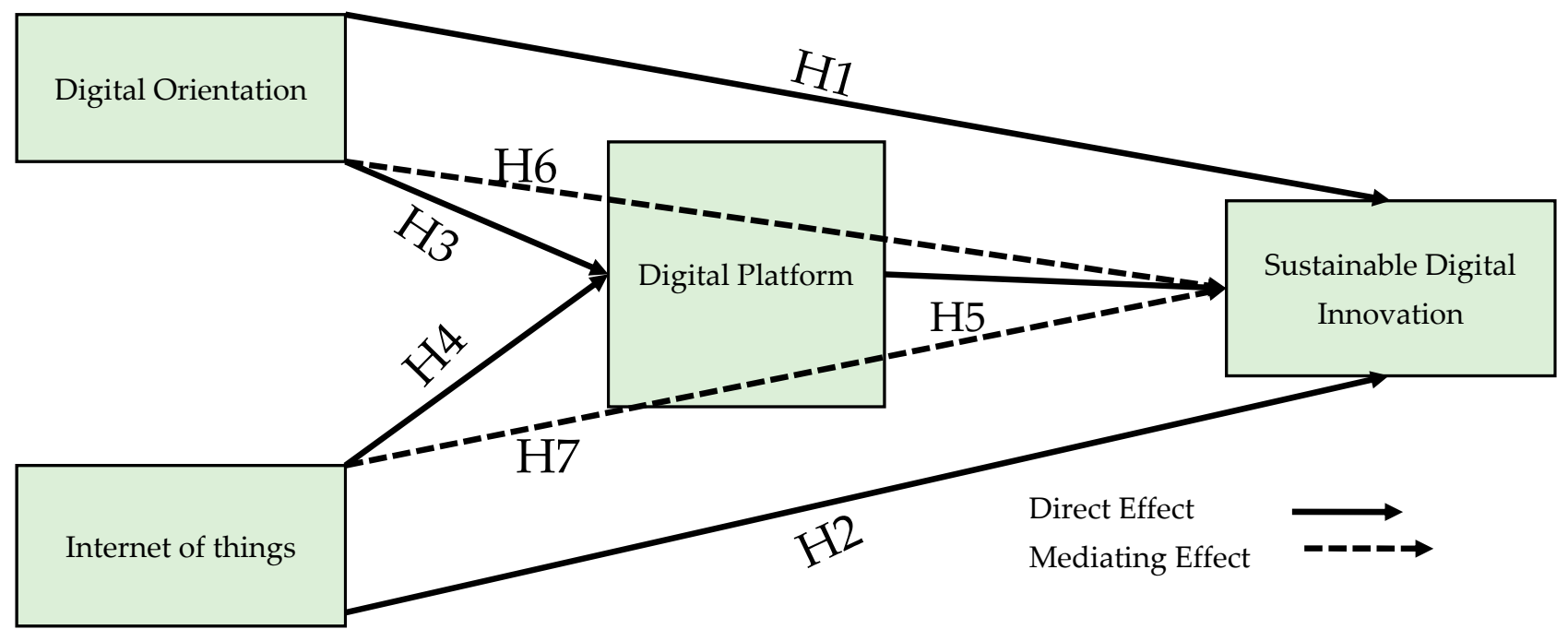

Figure 1. Theoretical framework. 


\section{Methodology}

\subsection{Data Collection}

A cross-sectional plan was used for the investigation of association among the constructs of the hypothesized model. To identify a representative sample, a list of SMEs was obtained from small and medium enterprises development authority (SMEDA) and small industrial development board of Khyber Pakthunkhwa (SIDB-KP). Data were collected from CEOs and managing directors of SMEs in Pakistan using convenient sampling. Sampling refers to the method which allows the researcher to draw inference regarding a population on the basis of results obtained from a smaller portion of the population [116]. Majority of the empirical studies use both probability and non-probability for getting observation keeping in view the nature of population [117]. As the characteristics of population for the current study were unknown, therefore, a non-probability sampling method was used to select the sample from the requisite population. Resultantly, the data obtained from Pakistan will not restrict application of this study to the other developing economies [62].

The structure of the SMEs is different from large scale enterprises and demonstrates dissimilar features. SMEs play a critical role for the development of economies of both developed and developing countries [62]. SMEs in Pakistan also have a major role for improving the living standard of country citizens by contributing more than $70 \%$ in GDP. Almost $80 \%$ of the labor force in Pakistan is employed by SMEs which represent almost $90 \%$ of the total economic organizations in Pakistan [61]. Due to the transformation of economy from traditional to digitalization economy, there is a dire need to update the structure of the SMEs in order to respond the emerging economies [57]. Therefore, the current study selected IT-based SMEs and empirically related the digital orientation of these SMEs with sustainable digital innovation. The selection of SMEs related to IT was evaluated through their business websites, Internet-based Buying/Selling links, E-Commerce and other digital-based operating activities.

The SMEs were selected for the data collection purpose and the data have been collected from those SMEs which are located in KPK and Punjab province of Pakistan. Four different criteria were confirmed for the data collection. First, SMEs should have been involved in online businesses activities, so they can have the complete set of digital operation from last 6 years. Second, SMEs have their own websites. Third, SMEs should have more than 100 employees. Finally, SMEs must have an IT Department which deals with upgrading its digitalized mechanism.

Data were collected with the help of 4 professional research assistants. These research assistants could collect 397 usable responses. The questionnaire was comprised of 2 sections; Section 1 asked 3 questions; respondent age, education and experience. Section 2 asked questions about the digital orientation, Internet of Things, digital platforms and sustainable digital innovation. All scales were measured using a 5-point Likert-scale " $\mathrm{SD}=1$ to SA $=5$ ". Likert scale is widely used in quantitative research because it is used as a universal mode for the collection of data and is easy to understand by the respondents. It is a form of ordered scale through which respondents can easily choose a given option that best aligns with their view and attitudes about a particular statement or question. However, we used the Likert scale in the current study as it is quantitative research design in nature.

\subsection{Measures}

To be sure about the reliability and validity of scales used in this research, we used pre-tested constructs of previous research (see Table A1 in Appendix A).

\subsubsection{Digital Orientation}

Digital orientation helps an organization to adopt digital practices and utilize latest technologies through proper orientation [8]. The use of digital technologies enables SMEs to attain the benefits of first mover in the operational industry. Digital orientation was measured through 4 items scales adapted from the work of Khin and Ho [82]. 


\subsubsection{Internet of Things}

IoT is the technological advancement which provides a world-wide platform for constant communication and connection all around the world using internet and devices connected to it [90]. IoT is one the best tools to perform all business activities. IoT was measured through a 9 item scale adapted from the work of De Vass et al. [90]. Most of the IoT-related items used in the applied questionnaire are the best related with the sustainable digital innovation concept.

\subsubsection{Digital Platform}

Digital platforms refer to the online platforms that connect different organizations and help businesses to regulate the communication processes for mutual benefits [32]. Digital platform was measured through an 8 item scale adapted from the work of Cenamor et al. [32].

\subsubsection{Sustainable Digital Innovation}

Sustainable digital innovation helps to implement the newest digital technology for achieving creative solutions that will address the social, economic and environmental business issues in the long-run [82]. It is a dominant combination of the digitalized technologies and digitalized management system for innovating the business processes in a sustainable way [31] and it is also based on the frugal innovation concept. Digital innovation was measured through 8 items, i.e., 6 items were adapted from the work of Khin and Ho [82] and 2 items were newly developed. The items of the sustainable digital innovation were adapted, given the focus on cutting the SMEs' costs and reducing the waste, considering the scarcity of resources that are specific to the developing countries.

\section{Analysis}

We used descriptive, correlation and SEM to test the hypotheses. To analyze the mediating role of digital platform, we used a 'Process' developed by Preacher and Hayes [118]. For the purpose of the data analysis, the current study has used the descriptive statistics, correlation, multiple hierarchical regressions techniques and structural equation modeling. Moreover, the discriminant validity was examined by using AMOS 7.0 software with the help of the confirmatory factor analysis (CFA). The aim of current study was to find out the liner relationships between variables used in hypothesized model. In order to examine the liner relationships, we employed a covariance approach. A covariance-based approach measures how two random variables change at the same time. On the other hand, variancebased approaches tell us that how the data set is spread around its mean value, while the covariance-based approach is used to determine the directional relationship between study variables. Discriminate validity was checked through Fornell and Lacker's approach [119]. The reliability of the construct was checked by using the value of Cronbach's $\alpha$. CFA results show that our model is fitted to the data. Discriminate validity was check through Fornell and Lacker's approach [119]. The reliability of the construct was checked by using the value of Cronbach's $\alpha$. CFA results show that our model is fitted to the data.

\subsection{Measurement}

CFA was utilized to test contract validity and model fitness. The reliability, discriminant validity and convergent validity were satisfactory (see Table 1 ). The reliability was confirmed and it ranges from 0.73 to 0.86 , showing that the construct used in this research is reliable. The discriminant validity and constructs validity were confirmed through CFA and factor loading is greater than 0.70. We have also applied Fornell and Larcker's approach [119] to measure the average variance extracted (AVE) and results show value of AVE is above than 0.50 , whereas Cronbach's $\alpha$ value is greater than 0.70 . 
Table 1. Results of alpha, CR and AVE.

\begin{tabular}{|c|c|c|c|c|c|}
\hline Variables Details & F-L & $t$-Value & Alpha & CR & AVE \\
\hline Digital Orientation & & & 0.89 & 0.85 & 0.74 \\
\hline DO1 & 0.75 & 15.41 & & & \\
\hline $\mathrm{DO} 2$ & 0.71 & 13.22 & & & \\
\hline DO3 & 0.73 & 14.56 & & & \\
\hline DO4 & 0.74 & 13.44 & & & \\
\hline Internet of Things & & & 0.88 & 0.96 & 0.73 \\
\hline IoT1 & 0.78 & 15.44 & & & \\
\hline IoT2 & 0.79 & 13.32 & & & \\
\hline IoT3 & 0.75 & 14.55 & & & \\
\hline IoT4 & 0.77 & 13.44 & & & \\
\hline IoT5 & 0.71 & 14.56 & & & \\
\hline IoT6 & 0.74 & 13.54 & & & \\
\hline IoT7 & 0.73 & 15.74 & & & \\
\hline IoT8 & 0.74 & 14.32 & & & \\
\hline IoT9 & 0.77 & 15.64 & & & \\
\hline Digital Platform & & & 0.87 & 0.94 & 0.75 \\
\hline DP1 & 0.73 & 13.96 & & & \\
\hline DP2 & 0.77 & 14.66 & & & \\
\hline DP3 & 0.79 & 13.32 & & & \\
\hline DP4 & 0.8 & 15.11 & & & \\
\hline DP5 & 0.75 & 14.21 & & & \\
\hline DP6 & 0.78 & 15.77 & & & \\
\hline DP7 & 0.72 & 13.74 & & & \\
\hline DP8 & 0.74 & 14.55 & & & \\
\hline $\begin{array}{l}\text { Sustainable Digital } \\
\text { Innovation }\end{array}$ & & & 0.86 & 0.93 & 0.78 \\
\hline DI1 & 0.76 & 14.22 & & & \\
\hline DI2 & 0.78 & 15.32 & & & \\
\hline DI3 & 0.77 & 13.55 & & & \\
\hline DI4 & 0.80 & 14.74 & & & \\
\hline DI5 & 0.76 & 15.21 & & & \\
\hline DI6 & 0.80 & 15.22 & & & \\
\hline DI7 & 0.71 & 15.21 & & & \\
\hline DI8 & 0.74 & 15.22 & & & \\
\hline
\end{tabular}

We have tested four different models to access the model fitness. The results are presented in Table 2. This shows that the results of our 4-factor model were fitted to the data $\left(\operatorname{RMSEA}=0.06, \chi^{2}=1021.34, \mathrm{df}=390 ; \chi^{2} / \mathrm{df}=2.619 ; \mathrm{CFI}=0.92 ; \mathrm{GFI}=0.91\right)$.

Table 2. CFA results.

\begin{tabular}{ccccccc}
\hline Model Detail & $\chi^{2}$ & Df & $\chi^{2} / \mathbf{d f}$ & RMESA & GFI & CFI \\
\hline $\begin{array}{c}\text { Hypothesized } \\
\text { four-factor model }\end{array}$ & 1021.34 & 390 & 2.619 & 0.06 & 0.91 & 0.92 \\
Three-factor model & 1174.65 & 360 & 3.263 & 0.15 & 0.88 & 0.89 \\
Two-factor model & 1244.58 & 310 & 4.015 & 0.22 & 0.71 & 0.72 \\
Single-factor model & 1236.21 & 290 & 4.263 & 0.26 & 0.64 & 0.65 \\
\hline
\end{tabular}

\subsection{Correlation Results}

Quantitative analysis is helpful for understanding the relationship among variables and the correlation shows level of association. In this study, the dependent variable is sustainable digital innovation (SDI) and major independent variables are IoT and digital orientation. To test the effect of independent variables on digital innovation, it is necessary to test correlation. Hence, this study conducted a correlation analysis which is presented in Table 3. Results proved that digital orientation is positively associated with the sustainable digital innovation $\left(\mathrm{r}=0.16^{* *}, p<0.0001\right)$. Our findings extended the work of a previous 
theory [35] who acknowledged that digital orientation determines intangible values. Our research hypothesized the IoT relates to SDI and results of correlation proved that IoT is positively associated with the sustainable digital innovation $\left(\mathrm{r}=0.17^{* *}, p<0.0001\right)$. These findings are supported by the work of Xiaocong et al. [41] and Nižetić [38] who proved that IoT develops platforms and improves digital innovation. Similarly, the digital platform is positively associated with the sustainable digital innovation $\left(\mathrm{r}=0.36^{* *}, p<0.00001\right)$. Digital platform builds eco-system [46] and digital platform is the key determinant of digital innovation [47]. To eliminate the risk of multi-collinearity, we used variance inflation factors (VIF). The value of VIF scores was less than 10.0, i.e., cut-toff value. Hence, multicollinearity is not an issue in this analysis.

Table 3. Correlation and descriptive values.

\begin{tabular}{|c|c|c|c|c|c|c|c|c|c|c|c|}
\hline & Variable & Mean & SD & 1 & 2 & 3 & 4 & 5 & 6 & 7 & 8 \\
\hline 1 & Age & 3.5 & 0.75 & 1 & & & & & & & \\
\hline 2 & Size & 2.6 & 0.69 & $0.105^{* *}$ & 1 & & & & & & \\
\hline 3 & $\begin{array}{l}\text { Respondent } \\
\text { Education }\end{array}$ & 2.8 & 0.59 & -0.28 & 0.24 & 1 & & & & & \\
\hline 4 & $\begin{array}{l}\text { Respondent } \\
\text { Experience }\end{array}$ & 2.9 & 0.56 & 0.66 & 0.33 & -0.2 & 1 & & & & \\
\hline 5 & Digital Orientation & 3.6 & 0.71 & 0.59 & -0.2 & -0.3 & 1 & 1 & & & \\
\hline 6 & Internet of things & 3.3 & 0.78 & 0.49 & -0.6 & -0.3 & -0.2 & $0.834^{* *}$ & 1 & & \\
\hline 7 & Digital Platform & 3.4 & 0.73 & -0.82 & 0.53 & $0.90 *$ & -0.1 & $0.255^{* *}$ & $0.348^{* *}$ & 1 & \\
\hline 8 & $\begin{array}{l}\text { Sustainable Digital } \\
\text { Innovation }\end{array}$ & 3.7 & 0.75 & -0.29 & -0.3 & -0.9 & -0.7 & $0.164^{* *}$ & $0.175^{* *}$ & $0.364^{* *}$ & 1 \\
\hline
\end{tabular}

Note: ${ }^{*} p<0.5,{ }^{* *} p<0.1$.

\subsection{Hypothesis Testing}

Structural equation modeling (SEM) was used for testing the hypotheses of this study. The results of the hypotheses show that all paths were significant and positively associated with each other (see Table 4). The digital orientation positively and significantly predicted the sustainable digital innovation ( $\left.\mathrm{B}=0.27^{* *}, p<0.0001\right)$; thus, $\mathrm{H} 1$ is accepted. IoT is positively and significantly linked with the sustainable digital innovation $\left(\mathrm{B}=0.17^{* *}\right.$, $p<0.000) ; \mathrm{H} 2$ is accepted. The digital orientation is positively and significantly connected with the digital platform $\left(\mathrm{B}=0.39^{* *}, p<0.0001\right)$; thus, $\mathrm{H} 3$ is accepted. Internet of Things is positively and significantly linked with the digital platform $\left(\mathrm{B}=0.34^{* *}, p<0.0001\right)$; so, H4 is accepted. The digital platform is positively and significantly linked with the sustainable digital innovation ( $\left.\mathrm{B}=0.25^{* *}, p<0.0001\right)$. Thus, $\mathrm{H} 5$ is accepted.

Table 4. Hypothesis testing.

\begin{tabular}{cccc}
\hline Hypothesis Detail & Effects & Coefficient & Remarks \\
\hline$(\mathrm{H} 1) \mathrm{DO} \rightarrow \mathrm{DI}$ & + & $0.27^{* *}$ & Accepted \\
$(\mathrm{H} 2) \mathrm{IoT} \rightarrow \mathrm{DI}$ & + & $0.17^{* *}$ & Accepted \\
$(\mathrm{H} 3) \mathrm{DO} \rightarrow \mathrm{DP}$ & + & $0.39^{* *}$ & Accepted \\
$(\mathrm{H} 4) \mathrm{IoT} \rightarrow \mathrm{DP}$ & + & $0.34^{* *}$ & Accepted \\
$(\mathrm{H} 5) \mathrm{DP} \rightarrow \mathrm{DI}$ & + & $0.25^{* *}$ & Accepted \\
\hline
\end{tabular}

Note: ${ }^{* *} p<0.1$.

\subsection{Mediating Role of the Digital Platform between the Digital Orientation and Sustainable Digital Innovation}

Table 5 shows the mediating role of the digital platform between the digital orientation and sustainable digital innovation. To conduct mediation tests, we have followed the instructions of Preacher and Hayes's approach [118]. According to their approach, the mediating role is confirmed with significant value of the indirect effect. The results show that the digital platform acts as a mediator between the digital orientation and sustainable digital innovation. (Beta $=0.1471$, lower value $=0.1894$, upper value $=0.2222$ ). We have 
also used the Soble test analysis " $\mathrm{Z}$ score" and the results proved that $\mathrm{Z}$ score $=5.74{ }^{* *}$ value was significant. Hence, $\mathrm{H} 6$ was accepted.

Table 5. Results of indirect H6.

\begin{tabular}{|c|c|c|c|c|c|c|}
\hline $\begin{array}{l}\text { Model } \\
\text { Detail }\end{array}$ & Data & Boot & Bias & SE & Lower & Upper \\
\hline $\mathrm{DO} \rightarrow \mathrm{DP} \rightarrow \mathrm{DI}$ & 0.1471 & 0.1463 & -0.0008 & 0.329 & 0.1894 & 0.2222 \\
\hline \multicolumn{7}{|c|}{ Soble Test Z Score $=5.74^{* *}$} \\
\hline
\end{tabular}

\subsection{Mediating Role of the Digital Platform between IoT and the Sustainable Digital Innovation}

Table 6 shows the mediating role of the digital platform between IoT and the sustainable digital innovation. The results show that the digital platform acts as a mediator between IoT and the sustainable digital innovation. (Beta $=0.1886$, lower value $=0.1247$, upper value $=0.2701$ ). We have also used the Soble test analysis " $Z$ score" and results proved that the $\mathrm{Z}$ score $=6.85^{* *}$ value was significant. Hence, $\mathrm{H} 7$ was accepted.

Table 6. Results of indirect H7.

\begin{tabular}{ccccccc}
\hline $\begin{array}{c}\text { Model } \\
\text { Detail }\end{array}$ & Data & Boot & Bias & SE & Lower & Upper \\
\hline IOT $\rightarrow$ DP $\rightarrow$ DI & 0.1886 & $\begin{array}{c}0.1871 \\
\text { Soble Test Z Score }=6.85^{* *}\end{array}$ & $\begin{array}{c}-0.0014 \\
\text { Note: } * *<<0.1 .0357\end{array}$ \\
\hline
\end{tabular}

\section{Discussion of the Results}

Digital technologies enable new businesses that incorporate new technology as a vital part of their business models and operations and this rapid development has significantly changed the competitive environment and redesigned traditional business strategies, models and processes [108,111].

This study was conducted to explore how SMEs can achieve the sustainable digital innovation in the digital economy. To achieve this purpose this study has investigated the direct impact of the digital orientation and IoT on the sustainable digital innovation and has also investigated the mediating role of the digital platform. H1 has proposed that the digital orientation predicts the sustainable digital innovation in SMEs. The results of $\mathrm{H} 1$ testing show there is a positive relationship between the digital orientation and the sustainable digital innovation. These findings have extended the research work of Linton and Solomon [85]. In the current digital-based economy, the digitalization has become the top priority of a large number of SMEs. The business transformation process into the digital form has made the digital orientation an evolving research stream that has the potential to efficiently meet innovation thrusts. The digital economy is based on the utilization of the information and communication technology in all the business activities. The SMEs that are operational in the digital economy are also involved in adopting the digital technology. This study uplifted the present understanding of the sustainable digital innovation by the digital orientation and ensured that digitalization efforts of many firms can leads to innovation. $\mathrm{H} 2$ of this study was also supported by the achieved results; thus, we can state that IoT determines the sustainable digital innovation. IoT in terms of Web technology including its hardware and software derives a large amount of information useful to develop the sustainable digital innovation into the business. Thus, the SMEs can attain new and innovative ideas. By testing the second hypothesis $\mathrm{H} 2$, it has been derived that the IoT has a positive influence on the sustainable digital innovation. This has extended the previous research work and findings of Kraus et al. [102]. These findings for H2 are supported by the work of Xiaocong et al. [41] and Nižetić [42] who proved that IoT develops platforms and improves digital innovation. 
The effect of the digital orientation on the digital platform was also tested by H3. The results have disclosed that the digital orientation can play a pivotal role in the utilization of the digital platforms. This supports the results of the previous research of Kraus et al. [102] or Jones-Evans and Klofsten [103] that proved the positive relationship between the digital orientation and the business platforms. The digital orientation helps to invest more in the development of the digital platforms to get benefits from it up to its full potential. The readiness of the management to invest in digital technology in the business organization allows the business to benefit from the online digital platforms for the businesses.

The link between the IoT and digital platforms is also tested by $\mathrm{H} 4$ and the results have shown that the relationship is a positive one. This has extended the previous work of Kirchner and Schußler [97] who have demonstrated the link between the internet and the digital platforms. Internet-related information and related platforms allow businesses to develop a new strategy in the old business context leading to the digital innovation. The results of $\mathrm{H} 5$ have also confirmed the relationship between the digital platform and the sustainable digital innovation. This result is according to the findings of Nambisan et al. [30]. Digital platform builds an eco-system [46] and digital platform is a key determinant of digital innovation [47].

Nambisan [120] has shown that digital technologies, in conjunction with an important characteristic of the digital platforms, contribute to the evolving emergence and evolution of entrepreneurial opportunities and to digital innovation.

H6 has shown that the digital platform positively mediates the relationship between the digital orientation and the sustainable digital innovation. This has extended the previous research findings of Esposito De Falco et al. [28]. More precisely, being digitallyoriented, the SMEs can achieve the sustainable digital innovation, but when this relationship is mediated by the digital platforms, the achievement of the sustainable digital innovation is certain. Hence, the SMEs cannot automatically achieve the sustainable digital innovation advancement except creating the digital platforms. Nevertheless, insights into the impact of the digital orientation on the digital innovation through the digital platforms are scarce in the existing literature. This study contributes to fill this research gap by examining the mediating effect of the digital platform capability between the digital orientation and sustainable digital innovation.

Furthermore, this study has also examined the mediation effect of the digital platform in the relationship between IoT and the sustainable digital innovation (H7). Thus, the results support the present understanding of the role played by the digital platform in the relationship between IoT and the sustainable digital innovation. The findings are according to those of the previous studies $[41,103]$. These studies showed that IoT brings benefits for both businesses and individuals and determines a continuous innovation and digital platforms help to collect relevant data, information and knowledge to increase the efficiency of all functions of businesses for achieving the digital innovation. It was proved that those SMEs, which are involved in the digital platforms initiated through IoT, and its peripherals can achieve the sustainable digital innovation. The results of testing each hypothesis are presented in Figure 2. 


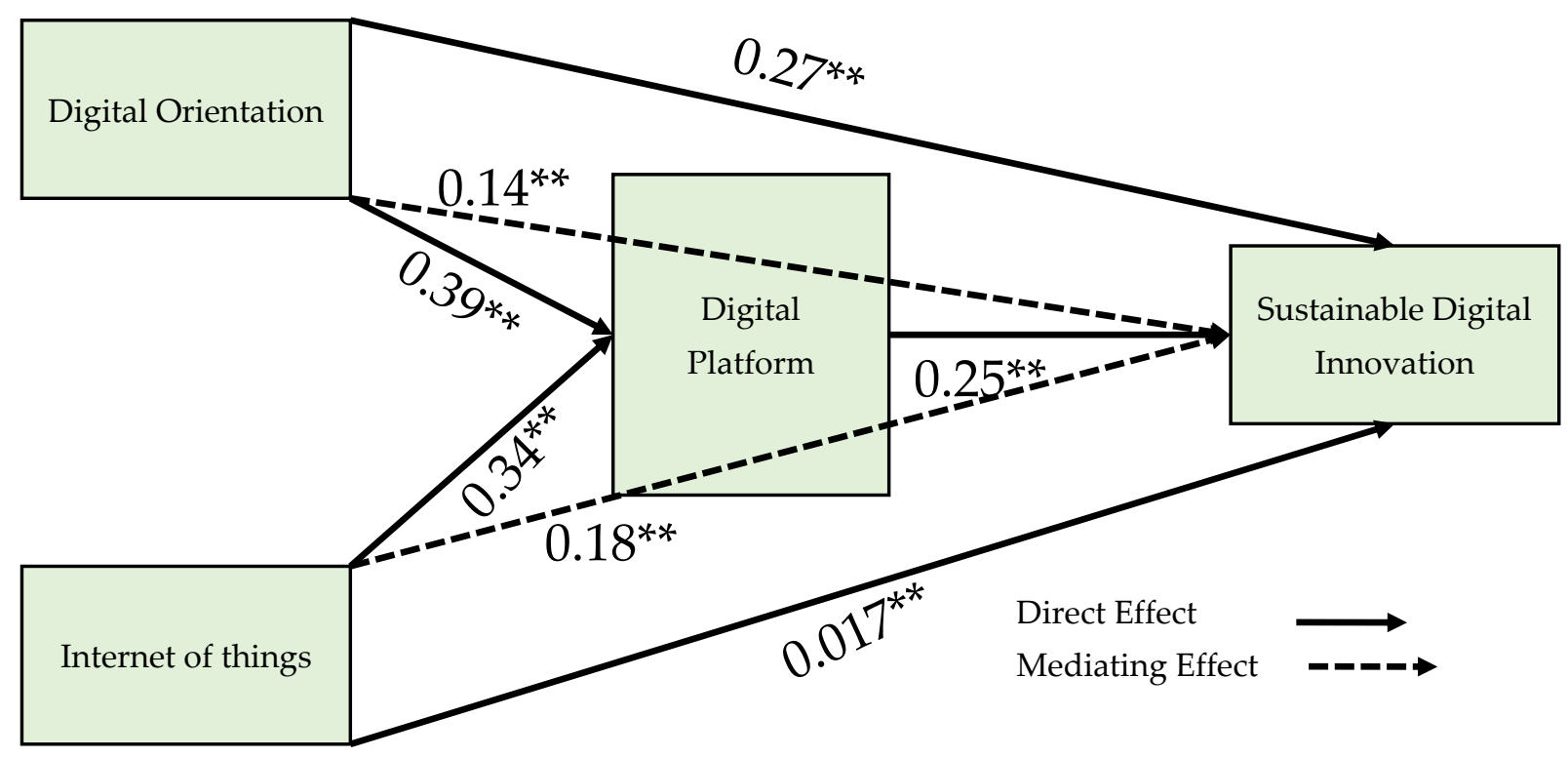

Figure 2. Results of hypotheses. Note: ${ }^{* *} p<0.1$.

\section{Conclusions}

Frugal sustainable innovation addresses the ecological issues, due to the high quality of products and long-lifetime, to social issues, because it solves some social problems by transferring the technology and innovations to the developing markets, and to economic issues because it addresses lower income markets with a high potential. All these goals can be reached by reducing functionality of the products and services to what is really necessary, being of high quality, durable, eco-friendly and sustainable at the same time.

Albert [65] in his study stated that the interest for frugal innovation is quite recent and this topic requires further research. He analyzed a wide literature on frugal innovation and concluded that most of the studies found a positive relation between the frugal innovation and social or economic dimensions of sustainability and only a high potential of frugal innovation in addressing environmental issues of sustainability by spill-over effects [121] or by side-effects, when it is targeting social or economic issues [122]. The existing literature, however, focused mainly on one specific dimension of sustainability (out of three dimensions) in relation with frugal innovation. Only few studies aimed at all three pillars of sustainability, but these were not empirical analyses [121-123]. Hence, ecological sustainable frugal innovation is normative, a more appropriate empirical research relates to the impact of ecological sustainable frugal innovation, how to design more ecological sustainable frugal innovation processes and outcomes, and how the results are different in developed vs. developing countries. Tiwari et al. [124] demonstrated that frugality is motivated by choice in developed countries, comparing to the lack of resources in the developing countries, but it can represent a sustainable solution also for the poor people from the developed countries. However, in their study, they proved that the diffusion of the frugal innovation is larger in the developing markets that lack large resources.

Le Bas [125] has proved that diffusion of the frugal innovation can be more often met into the business models based on services, because they combine product innovation with service innovation. The services sectors may be intensively using information technology for saving energy and resources, for reducing the waste. Although, the frugal innovation does not address mainly the environmental aims, it exhibits three important environmental properties: the ability to repair, to reuse and recycle the used components. In brief, it is linked to sustainability [125]. Frugal innovation minimizes resource use and supports the environmental sustainability [126] and therefore this requires a more in-depth approach.

The digital technologies allow this type of innovation which can make a huge contribution for achieving the SDGs up to 2030. Thus, the resources waste can be reduced 
and the products and services become more affordable and accessible. This can represent the best solution for the developing countries, but also the developed countries have their need for reducing the waste in relation with the environment. This study was conducted for a developing country, for the IT service sector, with the specific aim to analyze frugal digital innovation (its economic and environmental dimensions) in relation with some of its major determinant, digital orientation, digital technologies and digital platforms.

There is a gap in the existing studies on sustainable digital innovation that requires a further connected research to the digital technologies [30]. A major gap exists in defining the entrepreneurship in the digital age and in the digital economy frame [113].

Many countries consider digital entrepreneurship as a major determinant of the digital economic development. Thus, it is necessary to further research the digital entrepreneurship in relation to its major features and determinants [127].

This research has aimed to investigate both the direct and mediated impact of the digital orientation and IoT on the sustainable digital innovation in the developing countries. In this respect, seven hypotheses were built and tested. All of the hypotheses were validated by the applied statistical tests. This research has shown that the digital orientation and IoT significantly affect the digital platform. This study has developed a sustainable digital innovation model through digital orientation, IoT and digital platforms. It has also explored the relation between the digital platform and sustainable digital innovation and has tested the digital platforms as a mediator in both links between digital orientation-sustainable digital innovation and IoT-sustainable digital innovation and has proved that the digital platforms enhance the impact of the digital orientation and IoT on the sustainable digital innovation of SMEs in the context of their lack of large resources on the developing markets. These represent important findings for SMEs that are key participants on the markets [10], because they need to achieve the sustainable digital innovation for facing important challenges of the transforming digital economy and for improving their technical expertise in this frame [9].

\subsection{Theoretical Implications}

This research has several theoretical implications and provides an understanding of the sustainable digital innovation in the SMEs in different ways. Firstly, it shows that the digital orientation capability of the firm has a positive significant effect on the sustainable digital innovation. These findings have extended the existing knowledge in the current literature by expressing the interdependency of the SMEs on the digital technology that may induce enrichment in the digital innovation [128]. The major emphasis of this research is on the utilization of the digital platforms for achieving the sustainable digital innovation. Based on the recent research, which reflect the other advantages of the digital platforms, the findings of this study stress that the digital platform capability can significantly affect the sustainable digital innovation of SMEs. The results also suggest that successful SMEs can improve their digital innovativeness if the firm is digital-oriented via the digital platforms. Therefore, it is a major contribution in the existing literature of SMEs that these can achieve the latest form of innovation that is digitalized.

The findings of this research add to the theory by complementing the role of IoT on the sustainable digital innovation through the mediating role of the digital platforms [116,117]. This adds new findings to the existing literature because less work has been done so far on the digital platforms in relation to the improvement of the sustainable digital innovation for the SMEs. This study has suggested new ways for the adoption of the sustainable digital innovation in the case of SMEs, therefore it has extended the current knowledge related to the impact of the digital platforms in internet technology in the case of the emerging digital economies [41]. This research has also added new dimensions of knowledge in the technology acceptance model of the Rogers's theory [129]. It has linked the theories with the model of the sustainable digital innovation which is the new and latest concept. According to the Rogers's theory, the capability of innovation adoption affects the entrepreneurial decision [129]. SMEs have limited resources; therefore, the finding of this research can help 
the entrepreneurs of SMEs to allocate the capabilities and resources more effectively by bringing improvement in the entrepreneurial SMEs' planning for cutting the costs and reducing the waste.

Moreover, given the important role of R\&D in achieving sustainable innovations in the private sector, and in supporting the economic growth and development [130], a true partnership between public authorities and private organizations should be more and more implemented and should become very efficient in supporting R\&D in the private area. Suciu et al. [131] demonstrated in their study that a high-skilled labor force supports the digitalization of the economy, while $\mathrm{R} \& \mathrm{D}$ and innovation have a significant impact on economic growth and wellbeing.

\subsection{Managerial Implications}

This research has different practical implications. Due to the limitation of the resources and capabilities, the small and medium enterprises have a lack of data that is collected from stakeholders to achieve innovation. The management of the SMEs should adopt the digital platforms for the collection of big data as it is efficient to gather data through online platforms. The digital orientation and platforms-based approach present a model that enables the SMEs to gain benefits of the digital platforms. For instance, marketplaces, big data and crowd funding platforms offer some valuable opportunities to the management in terms of gaining new marketing ideas, new ways of accessing the markets and new value approach [132]. However, the achievement of the sustainable digital innovation is a complex approach, but this study provides insights to understand the multiple aspects of the digital platform and innovation. The results have also shown that the IoT has also a significant effect on the sustainable digital innovation, through digital platforms, because previous studies have showed that internet-based capabilities can affect the performance of the firm and the welfare of the entire society, as we mentioned in the previous sections of this study. In practice, the management should focus on achieving the sustainable digital innovation through implementing the digital platform-enhanced network capability initiated by the digital orientation and IoT. It is also suggested to the managers of entrepreneurial SMEs that they should get benefits of the digital economy by improving their digital innovativeness and by using the digital platforms and technologies. The results of the mediating effect of the digital platforms can help the managers of SMEs to focus on improving their digital platform capabilities [103]. By making this improvement, the firm can collect the digital innovative benefits. It can enable the small firms to achieve long-run sustainability and a high level of performance based on reducing the costs and the waste of resources. It is also suggested to the managers of the SMEs to enhance their capacities for the utilization of technology in their business.

\subsection{Limitations and Directions for Future Research}

This research also bears several limitations from the perspective of the model, findings and scope. This study focuses only on the sustainable digital innovation through the digital technologies. However, the digital platform capabilities and digital orientation can also affect the overall performance of the firms [133]. Therefore, a future research can be elaborated by considering the strategic business performance (other than digital innovation) through the digital technologies and platforms. Another interesting further research would be represented by the analysis between big data analytics capabilities or the governance of big data analytics infrastructure and the sustainable digital innovation achieved by SMEs because according to Bertello et al. there is a positive relation between those variables and the SMEs' expansion and growth [134]. An interesting further research can be elaborated based on a new methodological approach, by applying new criterion for testing the validity of the measurement scale [135], namely Heterotrait-Monotrait (HTMT) relationship instead of Fornell and Lacker criterion that was considered a lax one by some authors [136]. Another limitation of this research is that it has taken the sample of SMEs [137]. It has not considered a broader view of large businesses. In addition, 
we have not discussed the case of any special sector. In the future, this research can be extended in any specific large sector. For instance, future research can also be done by checking the effect of the digital orientation, platforms and internet on the sustainable digital innovation in the case of the hospitality sector [138]. Finally, the context of this current research was Pakistan in which the market scenarios for SMEs are different from other countries where the digital economy is in the developed phase. In the future, this topic can be explored more for other countries that do not rely on frugal innovation, but a classical innovation, based on top technologies. Moreover, a cross country analysis can be elaborated for comparison. This way, the effectiveness of adopting the different sustainable digital innovation scenarios in different countries can be checked. Furthermore, nexus of a direct or mediated relationship between the digital orientation and sustainable digital innovation can also be empirically tested in the future, by adding some mediating variables like customer feedback in the framework of a future research. Another major direction for a further research would be to analyze the negative effects determined by the digital innovation. In addition to the technical, organizational, and economic benefits brought by the 4 th Industrial Revolution, many researchers consider that it will also cause some negative effects such as rising unemployment, social stratification, threats to cyber security, violations of privacy and an increasing gap between the developed and poor countries [14]. This requires a further research to investigate also the negative effects in the social and economic area of using the digital technologies. We have also investigated here only the economic and environmental dimension of frugal digital innovation in the developing countries. It is necessary to extend the analysis by adding the social dimension of the frugal innovation in a further study.

Orientation is related with learning and the outcomes of learning always develop an understanding with existing stream of knowledge, i.e., develops a platform. Hence, this study used the digital orientation as independent and digital platform as mediator and sustainable digital innovation as dependent variables. Moreover, the targets of this study were to build a sustainable digital innovation model for SMEs which are operating in Hi Tech digital arena. Therefore, an explicit research study was required to investigate the impact of IoT and digital orientation on sustainable digital innovation directly and through a mediator digital platform. Moreover, World Economic Forum has demonstrated that IoT can support the SDGs achievement. It is estimated that industrial IoT will provide major economic value to the world economy until 2030 [72].

However, further research can analyze these multifaceted dimensions separately. There are a number of previous studies which considered the multifaceted dimensions into a single research framework. Yousaf and Majid [62] analyzed the independent variable based on four dimensions into a single construct and their dependent variable strategic business performance (SBP) was also a combination of different dimensions. However, as for future research, these variables could be studied more in-depth.

This study focused on IoT and digital orientation which are only some of the many digital enablers which can be considered to study digital/smart transformation or sustainable digital innovation. Hence, future research should consider AI or cognitive robotics, advanced analytics or virtual reality for finding a specific technology paradigm into a research framework.

Author Contributions: Conceptualization, and methodology, Z.Y. Software and validation, L.S. Formal analysis, Z.Y. Investigation, M.R., C.I.S. Resources, Z.Y. Data curation, L.S. Writing-original draft preparation, Z.Y. Writing—review and editing, M.R., L.M.P. Visualization, M.R. and Z.Y. Supervision, Z.Y. Project administration, Z.Y. All authors have read and agreed to the published version of the manuscript.

Funding: This research received no external funding. 
Institutional Review Board Statement: Both national and international standard were considered for the completion of current research, also approval was obtained from SMEDA (small \& medium size enterprises) for the collection of data from owner/managers of SMEs. The Institutional Review Board Letter No. GCMS/2021/ADM71. The current study didn't harm any humans or animals.

Informed Consent Statement: Informed consent was obtained from all subjects involved in the study. Written informed consent has been obtained from the patient(s) to publish this paper.

Data Availability Statement: The data that support the findings of this study are not publicly available due to respondents' confidentiality reasons. The data are not publicly available due to containing information that could compromise the privacy of the participants in this research.

Conflicts of Interest: The authors declare no conflict of interest.

\section{Appendix A}

Table A1. Details of the applied questionnaire and the relation between its questions and the variables used in the analysis.

\begin{tabular}{|c|c|c|}
\hline No. & Items & Source \\
\hline \multicolumn{3}{|c|}{ Digital Orientation } \\
\hline 1 & $\begin{array}{c}\text { We are committed to use digital technologies in developing our new } \\
\text { solutions (for managing our social, economic and ecological business } \\
\text { issues) }\end{array}$ & \multirow{4}{*}{ (Khin and Ho, 2019) } \\
\hline 2 & Our solutions are supported by the digital technology & \\
\hline 3 & New digital technology is readily accepted in our organization & \\
\hline 4 & $\begin{array}{c}\text { We always look out for opportunities to use digital technology in our } \\
\text { innovation }\end{array}$ & \\
\hline \multicolumn{3}{|c|}{ IoT } \\
\hline 1 & $\begin{array}{l}\text { Using IoT our firms can provide individual item level identification (thus } \\
\text { it reduces paper work) }\end{array}$ & \multirow{9}{*}{ (De Vass et al., 2018) } \\
\hline 2 & $\begin{array}{l}\text { Our firm provide unit level (e.g., container/box/pallet) identification } \\
\text { with the help of IoT (instead of banners that damage environment) }\end{array}$ & \\
\hline 3 & $\begin{array}{l}\text { Our firm can auto-captures data to monitor, track and trace operational } \\
\text { activities and people. }\end{array}$ & \\
\hline 4 & $\begin{array}{l}\text { We can measure business activities, processes and its environmental } \\
\text { conditions }\end{array}$ & \\
\hline 5 & $\begin{array}{l}\text { Using IoT, we can control business processes remotely (thus better } \\
\text { protecting the environment). }\end{array}$ & \\
\hline 6 & $\begin{array}{l}\text { IoT enables us to provide real-time information to optimize business } \\
\text { activities (hence reducing paper work) }\end{array}$ & \\
\hline 7 & $\begin{array}{l}\text { IoT enables us to provide real-time intelligence of business operations } \\
\text { (including managing environmental issues) }\end{array}$ & \\
\hline 8 & $\begin{array}{l}\text { We can provide large volumes and variety of data to apply data analytics } \\
\text { for tactical and strategic decision making (including diminishing the } \\
\text { resources waste and cutting down the costs). }\end{array}$ & \\
\hline 9 & $\begin{array}{l}\text { IoT helps us to strengthen communication and coordination between } \\
\text { operators (improving the overall efficiency) }\end{array}$ & \\
\hline
\end{tabular}


Table A1. Cont.

\begin{tabular}{|c|c|c|}
\hline No. & Items & Source \\
\hline \multicolumn{3}{|c|}{ Digital Platforms } \\
\hline 1 & $\begin{array}{l}\text { Our platform easily accesses data from our partners' IT systems Our } \\
\text { platform is easily adapted to include new partners }\end{array}$ & \multirow{8}{*}{ (Cenamor et al., 2019). } \\
\hline 2 & $\begin{array}{c}\text { Our platform provides seamless connection between our partners' IT } \\
\text { systems and our IT systems (e.g., forecasting, production, manufacturing, } \\
\text { shipment etc.) }\end{array}$ & \\
\hline 3 & $\begin{array}{c}\text { Our platform has the capability to exchange real-time information with } \\
\text { our partners }\end{array}$ & \\
\hline 4 & $\begin{array}{c}\text { Our platform easily aggregates relevant information from our partners' } \\
\text { databases (e.g., operating information, business customer performance, } \\
\text { cost information etc.) (thus it addresses to the social and economic goals } \\
\text { of the firms and their partners) }\end{array}$ & \\
\hline 5 & Our platform is easily adapted to include new partners & \\
\hline 6 & $\begin{array}{l}\text { Our platform can be easily extended to accommodate new IT applications } \\
\text { or functions }\end{array}$ & \\
\hline 7 & $\begin{array}{c}\text { Our platform employs standards that are accepted by most current and } \\
\text { potential partners }\end{array}$ & \\
\hline 8 & $\begin{array}{l}\text { Our platform consists of modular software components, most of which } \\
\text { can be reused in other business application }\end{array}$ & \\
\hline \multicolumn{3}{|c|}{ Sustainable Digital Innovation } \\
\hline 1 & $\begin{array}{c}\text { The quality-price ratio of our digital solutions is superior compared to our } \\
\text { competitors' }\end{array}$ & \multirow{6}{*}{ (Khin and Ho, 2019) } \\
\hline 2 & $\begin{array}{l}\text { The features of our digital solutions are superior compared to our } \\
\text { competitors' }\end{array}$ & \\
\hline 3 & $\begin{array}{l}\text { The applications of our digital solutions are totally different from our } \\
\text { competitors' }\end{array}$ & \\
\hline 4 & $\begin{array}{l}\text { Our digital solutions are different from our competitors' in terms of } \\
\text { product platform }\end{array}$ & \\
\hline 5 & $\begin{array}{l}\text { Our new digital solutions are minor improvements of existing products, } \\
\text { at lower costs }\end{array}$ & \\
\hline 6 & $\begin{array}{c}\text { Some of our digital solutions are new to the market at the time of } \\
\text { launching (and they address to social, economic and ecological business } \\
\text { issues) }\end{array}$ & \\
\hline 7 & $\begin{array}{l}\text { Our digital innovations/solutions are based on cutting the costs and } \\
\text { reducing the waste when we launch products }\end{array}$ & Newly developed \\
\hline 8 & $\begin{array}{l}\text { Our digital innovations/solutions is cost saving and we aim to rely on the } \\
\text { frugal innovation when entering in new markets }\end{array}$ & Newly developed \\
\hline
\end{tabular}

\section{References}

1. Oliveira, T.A.; Oliver, M.; Ramalhinho, H. Challenges for Connecting Citizens and Smart Cities: ICT, E-Governance and Blockchain. Sustainability 2020, 12, 2926. [CrossRef]

2. Bukht, R.; Heeks, R. Defining, conceptualizing and measuring the digital economy. Development Informatics working paper. Int. Organ. Res. J. 2018, 13, 143-172.

3. Barefoot, K.; Curtis, D.; Jolliff, W.; Nicholson, J.R.; Omohundro, R. Defining and Measuring the Digital Economy; US Department of Commerce Bureau of Economic Analysis: Washington, DC, USA, 2018. Available online: https://www.bea.gov/digitaleconomy/_pdf/defining-and-measuring-the-digital-economy.pdf (accessed on 21 November 2020).

4. Ciriello, R.; Richter, A.; Schwabe, G. Digital Innovation. Bus. Inf. Syst. Eng. 2018, 60, 563-569. [CrossRef]

5. Fichman, R.G.; Dos Santos, B.L.; Zheng, Z. Digital innovation as a fundamental and powerful concept in the information systems curriculum. MIS Q. 2014, 38, 329-343. [CrossRef]

6. Scuotto, V.; Arrigo, E.; Candelo, E.; Nicotra, M. Ambidextrous innovation orientation effected by the digital transformation. Bus. Process. Manag. J. 2019, 26, 1121-1140. [CrossRef]

7. Hess, T.; Matt, C.; Benlian, A.; Wiesböck, F. Options for formulating a digital transformation strategy. MIS Q. Exec. 2016, 15, 123-139.

8. Quinton, S.; Canhoto, A.; Molinillo, S.; Pera, R.; Budhathoki, T. Conceptualizing a digital orientation: Antecedents of supporting SME performance in the digital economy. J. Strateg. Mark. 2018, 26, 427-439. [CrossRef] 
9. Nguyen, T.H.; Newby, M.; Macaulay, M.J. Information technology adoption in small business: Confirmation of a proposed framework. J. Small Bus. Manag. 2015, 53, 207-227. [CrossRef]

10. Matthews, C.H.; Hechavarria, D.; Schenkel, M.T. Family Business: A Global Perspective from the Panel Study of Entrepreneurial Dynamics and the Global Entrepreneurship Monitor. In Understanding Family Businesses: Undiscovered Approaches, Unique Perspectives and Neglected Topics; Carsrud, A.L., Brännback, M., Eds.; Springer: New York, NY, USA, 2012; pp. 9-26.

11. Carsrud, A.; Cucculelli, M. Family firms, entrepreneurship, and economic development. J. Small Bus. Manag. 2014, 52, 189-191. [CrossRef]

12. Yoo, Y.; Hendfridsson, O.; Lyytinen, K. The new organizing logic of Digital Innovation. An Agenda Information System Research. Inf. Syst. Res. 2010, 21, 724-735. [CrossRef]

13. Maciejewski, M.; Głodowska, A. Economic development versus the growing importance of the financial sector: Global insight. Int. Entrep. Rev. 2020, 6, 77-90.

14. Rymarczyk, J. Technologies, Opportunities and Challenges of the Industrial Revolution 4.0: Theoretical Considerations. Entrep. Bus. Econ. Rev. 2020, 8, 185-198. [CrossRef]

15. Rymarczyk, J. The impact of industrial revolution 4.0 on international trade. Entrep. Bus. Econ. Rev. 2021, 9, 105-117.

16. Hinings, B.; Gegenhuber, T.; Greenwood, R. Digital innovation and transformation: An institutional perspective. Inf. Organ. 2018, 28, 52-61. [CrossRef]

17. Nylén, D.; Holmström, J. Digital innovation strategy: A framework for diagnosing and improving digital product and service innovation. Bus. Horiz. 2015, 58, 57-67. [CrossRef]

18. Lee, J.; Berente, N. Digital innovation and the division of innovative labour: Digital controls in the automotive industry. Organ. Sci. 2012, 23, 1428-1447. [CrossRef]

19. Demirkan, H.; Spohrer, J.C.; Welser, J.J. Digital innovation and strategic transformation. IT Prof. 2016, 18, 14-18. [CrossRef]

20. Dery, K.; Sebastian, I.M.; van der Meulen, N. The Digital Workplace is Key to Digital Innovation. MIS Q. Exec. 2017, 16, 135-152.

21. Chae, B.K. A General framework for studying the evolution of the digital innovation ecosystem: The case of big data. Int. J. Inf. Manag. 2019, 45, 83-94. [CrossRef]

22. Huesig, S.; Endres, H. Exploring the digital innovation process. Eur. J. Innov. Manag. 2019, 22, 302-314. [CrossRef]

23. Sambamurthy, V.; Bharadwaj, A.; Grover, V. Shaping agility through digital options: Reconceptualizing the role of information technology in contemporary firms. MIS Q. 2003, 27, 237-263. [CrossRef]

24. Shahzad, F.; Xiu, G.; Shahbaz, M. Organizational culture and innovation performance in Pakistan's software industry. Technol. Soc. 2017, 51, 66-73. [CrossRef]

25. Yoo, Y.; Lyytinen, K.; Yang, H. The role of standards in innovation and diffusion of broadband mobile services: The case of South Korea. J. Strateg. Inf. Syst. 2005, 14, 323-353. [CrossRef]

26. Lokuge, S.; Sedera, D.; Grover, V.; Dongming, X. Organizational readiness for digital innovation: Development and empirical calibration of a construct. Inf. Manag. 2019, 56, 445-461. [CrossRef]

27. Lin, H.F. Empirically testing innovation characteristics and organizational learning capabilities in e-business implementation success. Int. Res. 2008, 18, 60-78. [CrossRef]

28. Esposito De Falco, S.; Renzi, A.; Orlando, B.; Cucari, N. Open collaborative innovation and digital platforms. Prod. Plan. Control. 2017, 28, 1344-1353. [CrossRef]

29. Chan, C.M.; Teoh, S.Y.; Yeow, A.; Pan, G. Agility in responding to disruptive digital innovation: Case study of an SME. Inf. Syst. J. 2019, 29, 436-455. [CrossRef]

30. Nambisan, S.; Lyytinen, K.; Majchrzak, A.; Song, M. Digital Innovation Management: Reinventing innovation management research in a digital world. MIS Q. 2017, 41, 223-228. [CrossRef]

31. Zairis, A.G. The Effective Use of Digital Technology by SMEs. In Entrepreneurial Development and Innovation in Family Businesses and SMEs; Masouras, A., Maris, G., Kavoura, A., Eds.; IGI Global: Hershey, PA, USA, 2020; pp. $244-255$.

32. Cenamor, J.; Parida, V.; Wincent, J. When plentiful platforms payoff: Assessment orientation moderates the effect of assortment size on choice engagement and product valuation. J. Retail. 2019, 93, 212-227.

33. Yoo, Y.; Boland, R.J., Jr.; Lyytinen, K.; Majchrzak, A. Organizing for innovation in the digitized world. Organ. Sci. 2012, 23, 1398-1408. [CrossRef]

34. Garcia De Lomana, G.; Strese, S.; Brinckmann, J. Adjusting to the digital age: The effects of TMT characteristics on the digital orientation of firms. In Academy of Management Proceedings. Briarcliff Manor, NY 10510. Acad. Manag. 2019, 1, 13589.

35. Beutel, S.; Bendig, D.; Brettel, M. The Intangible Value of Digitalization-Assessing the Relationship of Digital Orientation and Intangible Value Drivers. In Proceedings of the 40th ICIS 2019 Conference, Munich, Germany, 15-18 December 2019. Available online: https:/ / aisel.aisnet.org/icis2019/governance_is/governance_is/24/(accessed on 1 January 2021).

36. Törmer, R.L. Internal Digital Platforms and Generative Mechanisms of Digital Innovation. In Proceedings of the 39th International Conference on Information Systems (ICIS), San Francisco, CA, USA, 13-16 December 2018; Association for Information Systems. AIS Electronic Library (AISeL), 2018. Available online: https:/ /icis2018.aisconferences.org/ (accessed on 20 December 2020).

37. Wang, C.L. Entrepreneurial orientation, learning orientation, and firm performance. Entrep. Theory Pract. 2008, 32, 635-656. [CrossRef]

38. Theodosiou, M.; Kehagias, J.; Katsikea, E. Strategic Orientations, marketing capabilities and firm performance: An empirical investigation in the context of frontline managers in service organisations. Ind. Mark. Manag. 2012, 41, 1058-1070. [CrossRef] 
39. Zhou, K.Z.; Yim, C.K.B.; Tse, D.K. The effects of strategic orientations on technology- and market-based breakthrough innovations. J. Mark. 2005, 69, 42-60. [CrossRef]

40. Hagel, J.I.; Brown, J.S.; Davison, L. The big shift: Measuring the forces of change. Harv. Bus. Rev. 2009, 87, 86-89.

41. Xiaocong, Q.; Jidong, Z. Study on the structure of "Internet of Things (IOT)" business operation support platform. In Proceedings of the 2010 IEEE 12th International Conference on Communication Technology, Nanjing, China, 10 June 2010; pp. $1068-1071$.

42. Nižetić, S.; Šolić, P.; González-de-Artaza, D.L.; Patrono, L. Internet of Things (IoT): Opportunities, issues and challenges towards a smart and sustainable future. J. Clean. Prod. 2020, 274, 122877. [CrossRef] [PubMed]

43. Richter, C.; Kraus, S.; Brem, A.; Durst, S.; Giselbrecht, C. Digital entrepreneurship: Innovative business models for the sharing economy. Creat. Innov. Manag. 2017, 26, 300-310. [CrossRef]

44. Asadullah, A.; Faik, I.; Kankanhalli, A. Digital Platforms: A Review and Future Directions, Literature Review on Digital Platform, Twenty-Second Pacific Asia Conference on Information Systems, Japan, 2018. Available online: https://www. researchgate.net/publication/327971665_Digital_Platforms_A_Review_and_Future_Directions\#fullTextFileContent (accessed on 31 December 2020).

45. Parker, G.G.; Van Alstyne, M.W.; Choudary, S.P. Platform Revolution: How Networked Markets are Transforming the Economy and How to Make Them Work for You; WW Norton \& Co: New York, NY, USA, 2016.

46. Hein, A.; Schreieck, M.; Riasanow, T.; Setzke, D.S.; Wiesche, M.; Böhm, M.; Krcmar, H. Digital platform ecosystems. Electron. Mark. 2020, 30, 87-98. [CrossRef]

47. Helfat, C.E.; Raubitschek, R.S. Dynamic and integrative capabilities for profiting from innovation in digital platform-based ecosystems. Res. Policy 2018, 47, 1391-1399. [CrossRef]

48. Hagiu, A.; Wright, J. Marketplace or Reseller? Manag. Sci. 2015, 61, 184-203. [CrossRef]

49. Chan, J.; Ghose, A. Internet's Dirty Secret: Assessing the Impact of Online Intermediaries on HIV Transmission. MIS Q. 2014, 38, 955-975. [CrossRef]

50. Kazan, E.; Tan, C.W.; Lim, E.T.; Sørensen, C.; Damsgaard, J. Disentangling digital platform competition: The case of UK mobile payment platforms. J. Manag. Inf. Syst. 2018, 35, 180-219. [CrossRef]

51. Yablonsky, S. A multidimensional framework for digital platform innovation and management: From business to technological platforms. Syst. Res. Behav. Sci. 2018, 35, 485-501. [CrossRef]

52. Pagani, M. Digital Business Strategy and Value Creation: Framing the Dynamic Cycle of Control Points. MIS Q. 2013, 37, 617-632. [CrossRef]

53. Tiwana, A.; Konsynski, B.; Bush, A.A. Platform evolution: Coevolution of platform architecture, governance, and environmental dynamics. Inf. Syst. Res. 2010, 21, 675-687. [CrossRef]

54. Faraj, S.; Krogh, G.; Von Monteiro, E.; Lakhani, K.R. Online Community as Space for Knowledge Flows. Inf. Syst. Res. 2016, 27, 668-684. [CrossRef]

55. Oppong-Tawiah, D.; Bassellier, G. Digital Innovation, Platform Orientation and the Performance of IT Start-ups. In Proceedings of the 38th Conference ICIS 2017 Proceedings, Seoul, Korea, 10-13 December 2017; pp. 1-11.

56. Kotsev, A.; Schade, S.; Craglia, M.; Gerboles, M.; Spinelle, L.; Signorini, M. Next generation air quality platform: Openness and Interoperability for the internet of things. Sensors 2016, 16, 403. [CrossRef]

57. De Bernardi, P.; Forliano, C.; Bertello, A. Digital Transformation in SMEs: A Systematic Review and Future Directions. In Proceedings of the 13th Annual Conference of the EuroMed Academy of Busines, Palermo, Sicily, Italy, 9-10 September 2020; pp. 308-325. Available online: https:/ / emrbi.org/wp-content/uploads/2020/10/EuroMed-13-19.10.20.pdf (accessed on 23 December 2020).

58. Garzoni, A.; De Turi, I.; Secundo, G.; Del Vecchio, P. Fostering digital transformation of SMEs: A four levels approach. Manag. Decis. 2020, 58, 1543-1562. [CrossRef]

59. Rachinger, M.; Rauter, R.; Müller, C.; Vorraber, W.; Schirgi, E. Digitalization and its influence on business model innovation. J. Manuf. Technol. Manag. 2019, 30, 1143-1160. [CrossRef]

60. Khan, S.; Khan, S.; Aftab, M. Digitalization and its impact on the economy. Int. J. Digit. Libr. Serv. 2015, 5, 138-149.

61. Yousaf, Z.; Sahar, N.; Majid, A.; Rafiq, A. The effects of e-marketing orientation on strategic business performance: Mediating role of e-trust. World J. Entrep. Manag. Sustain. Dev. 2018, 14, 309-320. [CrossRef]

62. Yousaf, Z.; Majid, A. Organizational network and strategic business performance. J. Organ. Chang. Manag. 2018, 31, 2-22. [CrossRef]

63. Ananthram, S.; Chan, C. Institutions and frugal innovation: The case of Jugaad. Asia Pac. J. Manag. 2019, 38, 1-30. [CrossRef]

64. Thun, E. Innovation at the middle of the pyramid: State policy, market segmentation, and the Chinese automotive sector. Technovation 2018, 70, 7-19. [CrossRef]

65. Albert, M. Sustainable Frugal Innovation-The connection between frugal innovation and sustainability. J. Clean. Prod. 2019, 237, 117747. [CrossRef]

66. Levänen, J.; Hossain, M.; Lyytinen, T.; Hyvärinen, A.; Numminen, S.; Halme, M. Implications of frugal innovations on sustainable development: Evaluating water and energy innovations. Sustainability 2016, 8, 4. [CrossRef]

67. Howell, R.; van Beers, C.; Doorn, N. Value capture and value creation: The role of information technology in business models for frugal innovations in Africa. Technol. Forecast. Social Chang. 2018, 131, 227-239. [CrossRef] 
68. Mourtzis, D.; Vlachou, E.; Boli, N.; Gravias, L.; Giannoulis, C. Manufacturing networks design through smart decision making towards frugal innovation. Procedia Cirp. 2016, 50, 354-359. [CrossRef]

69. Le Bas, C. Frugal innovation, sustainable innovation, reverse innovation: Why do they look alike? Why are they different? J. Innov. Econ. Manag. 2016, 21, 9-26.

70. Basu, R.; Banerjee, P.; Sweeny, E. Frugal Innovation: Core Competencies to Address Global Sustainability. J. Manag. Glob. Sustain 2013, 1, 63-82. [CrossRef]

71. Bican, P.M.; Brem, A. Digital Business Model, Digital Transformation, Digital Entrepreneurship: Is There A Sustainable "Digital"? Sustainability 2020, 12, 5239. [CrossRef]

72. Ordieres-Meré, J.; Prieto Remón, T.; Rubio, J. Digitalization: An Opportunity for Contributing to Sustainability from Knowledge Creation. Sustainability 2020, 12, 1460. [CrossRef]

73. Hoogendoorn, B.; van der Zwan, P.; Thurik, R. Sustainable entrepreneurship: The role of perceived barriers and risk. J. Bus. Ethics 2017, 175, 1133-1154. [CrossRef]

74. Merrill, R.K.; Schillebeeckx, S.J.D.; Blakstad, S. Sustainable Digital Finance in Asia: Creating Environmental Impact through Bank Transformation. SDFA, DBS, UN Environment. 2019. Available online: https:/ /www.dbs.com/iwov-resources/images/ sustainability/reports/Sustainable\%20Digital\%20Finance\%20in\%20Asia_FINAL_22.pdf (accessed on 12 November 2020).

75. George, G.; Merrill, R.K.; Schillebeeckx, S.J. Digital Sustainability and Entrepreneurship: How Digital Innovations Are Helping Tackle Climate Change and Sustainable Development. Entrep. Theory Pract. 2020. [CrossRef]

76. Secundo, G.; Ndou, V.; Del Vecchio, P.; De Pascale, G. Sustainable development, intellectual capital and technology policies: A structured literature review and future research agenda. Technol. Forecast. Soc. Chang. 2020, 153, 119917. [CrossRef]

77. Holmström, J.; Liotta, G.; Chaudhuri, A. Sustainability outcomes through direct digital manufacturing-based operational practices: A design theory approach. J. Clean. Prod. 2017, 167, 951-961. [CrossRef]

78. World Economic Forum Here's How Digital Transformation Will Create a More Sustainable World. World Economic Forum Annual Meeting. 2020. Available online: https://www.weforum.org/agenda/2020/01/digital-transformation-sustainableworld/ (accessed on 15 November 2020).

79. Kane, G.C.; Palmer, D.; Phillips, A.N.; Kiron, D.; Buckley, N. Strategy, not technology, drives digital transformation. MIT Sloan Manag. Rev. 2015, 14, 1-25.

80. Kane, G.C.; Palmer, D.; Phillips, A.N.; Kiron, D.; Buckley, N. Aligning the organization for its digital future. MIT Sloan Manag. Rev. 2016, 57, 1-25.

81. Brenner, B. Transformative Sustainable Business Models in the Light of the Digital Imperative-A Global Business Economics Perspective. Sustainability 2018, 10, 4428. [CrossRef]

82. Khin, S.; Ho, T.C. Digital technology, digital capability and organizational performance. Int. J. Innov. Sci. 2019, 11, 177-195. [CrossRef]

83. Chen, J.; Zhang, R.; Wu, D. Equipment Maintenance Business Model Innovation for Sustainable Competitive Advantage in the Digitalization Context: Connotation, Types, and Measuring. Sustainability 2018, 10, 3970. [CrossRef]

84. Yusupov, K.; Kosarev, V.; Mukhametzyanov, A.; Philippova, E.; Gavrilov, A.; Safiullin, A.; Klygach, D. Compact digital orientation module for borehole logging tools. In Proceedings of the 2018 IEEE East-West Design \& Test Symposium (EWDTS), Kazan, Russia, 14-17 September 2018; pp. 1-4.

85. Linton, J.D.; Solomon, G.T. Technology, innovation, entrepreneurship and the small business-Technology and innovation in small business. J. Small Bus. Manag. 2017, 55, 196-199. [CrossRef]

86. Al-Emran, M.; Mezhuyev, V.; Kamaludin, A. Technology Acceptance Model in M-learning context: A systematic review. Comput. Educ. 2018, 125, 389-412. [CrossRef]

87. Bach, M.P.; Čeljo, A.; Zoroja, J. Technology acceptance model for business intelligence systems: Preliminary research. Procedia Comput. Sci. 2016, 100, 995-1001. [CrossRef]

88. Steininger, D.M. Linking information systems and entrepreneurship: A review and agenda for IT-associated and digital entrepreneurship research. Inf. Syst. J. 2018, 29, 363-407. [CrossRef]

89. Standing, C.; Mattsson, J. Fake it until you make it: Business model conceptualization in digital entrepreneurship. J. Strateg. Mark. 2018, 26, 385-399. [CrossRef]

90. De Vass, T.; Shee, H.; Miah, S.J. The effect of "Internet of Things" on supply chain integration and performance: An organizational capability perspective. Australas. J. Inf. Syst. 2018, 22, 1-29. [CrossRef]

91. Kupriyanovsky, V.; Sneps-Sneppe, M.; Namiot, D.; Seleznev, S.; Sinyagov, S.; Kupriyanovsky, J. Web of Things and Internet of Things in the Digital Economy. Int. J. Open Inf. Technol. 2017, 5, 38-45.

92. Pasolini, G.; Buratti, C.; Feltrin, L.; Zabini, F.; De Castro, C.; Verdone, R.; Andrisano, O. Smart city pilot projects using LoRa and IEEE802.15.4 technologies. Sensors 2018, 18, 1118. [CrossRef]

93. Bahga, A.; Madisetti, V.K. Blockchain platform for industrial internet of things. J. Softw. Eng. Appl. 2016, 9, 533-546. [CrossRef]

94. Tanwar, S.; Patel, P.; Patel, K.; Tyagi, S.; Kumar, N.; Obaidat, M.S. An Advanced Internet of Thing-Based Security Alert System for Smart Home. In Proceedings of the 2017 International Conference on Computer, Information and Telecommunication Systems (CITS), Dalian, China, 21-23 July 2017; pp. 25-29.

95. Scuotto, V.; Santoro, G.; Bresciani, S.; Del Giudice, M. Shifting intra-and inter-organizational innovation processes towards digital business: An empirical analysis of SMEs. Creat. Innov. Manag. 2017, 26, 247-255. [CrossRef] 
96. Ahram, T.; Sargolzaei, A.; Sargolzaei, S.; Daniels, J.; Amaba, B. Blockchain technology innovations. In Proceedings of the 2017 IEEE Technology \& Engineering Management Conference (TEMSCON), Santa Clara, CA, USA, 8-10 June 2017; pp. $137-141$.

97. Kirchner, S.; Schüßler, E. The organization of digital marketplaces: Unmasking the role of Internet platforms in the sharing economy. In Organization Outside Organizations. The Abundance of Partial Organization in Social Life; Göran, A., Nils, B., Eds.; Cambridge University Press: Cambridge, UK, 2019; pp. 131-154.

98. Viriyasitavat, W.; Da Xu, L.; Bi, Z.; Pungpapong, V. Blockchain and Internet of Things for Modern Business Process in Digital Economy-The state of the art. IEEE Trans. Comput. Soc. Syst. 2019, 6, 1420-1432. [CrossRef]

99. Abdelgawad, A.; Yelamarthi, K. Internet of things (IoT) platform for structure health monitoring. Wirel. Commun. Mob. Comput. 2017, 1, 1-10. [CrossRef]

100. Eaton, B.D. The dynamics of digital platform innovation: Unfolding the paradox of control and generativity in Apple's iOS. Doctoral Dissertation, The London School of Economics and Political Science (LSE), London, UK, 2012. Available online: http:/ / etheses.lse.ac.uk/463/ (accessed on 1 January 2021).

101. De Luca, L.; Busayarat, C.; Stefani, C.; Véron, P.; Florenzano, M. A semantic-based platform for the digital analysis of architectural heritage. Comput. Graph. 2011, 35, 227-241. [CrossRef]

102. Kraus, S.; Palmer, C.; Kailer, N.; Kallinger, F.L.; Spitzer, J. Digital entrepreneurship: A research agenda on new business models for the twenty-first century. Int. J. Entrep. Behav. Res. 2019, 25, 353-375. [CrossRef]

103. Jones-Evans, D.; Klofsten, M. (Eds.) Technology, Innovation and Enterprise: The European Experience; Palgrave Macmillan: London, UK, 2016.

104. Osterrieder, P.; Budde, L.; Friedli, T. The smart factory as a key construct of industry 4.0: A systematic literature review. Int. J. Prod. Econ. 2020, 221, 107476. [CrossRef]

105. Svensson, R.B.; Taghavianfar, M. Selecting creativity techniques for creative requirements: An evaluation of four techniques using creativity workshops. In Proceedings of the IEEE 23rd International Requirements Engineering Conference, Ottawa, ON, Canada, 24-28 August 2015; pp. 66-75.

106. Tarakanov, V.V.; Inshakova, A.O.; Dolinskaya, V.V. Information society, digital economy and law. In Ubiquitous Computing and the Internet of Things: Prerequisites for the Development of ICT; Popkova, E., Ed.; Studies in Computational Intelligence; Springer: Berlin/Heidelberg, Germany, 2019; Volume 826, pp. 3-15.

107. Jin, H.; Hurd, F. Exploring the impact of digital platforms on SME internationalization: New Zealand SMEs use of the Alibaba platform for Chinese market entry. J. Asia-Pac. Bus. 2018, 19, 72-95. [CrossRef]

108. Elia, G.; Margherita, A.; Passiante, G. Digital entrepreneurship ecosystem: How digital technologies and collective intelligence are reshaping the entrepreneurial process. Technol. Forecast. Social Chang. 2020, 150, 119791. [CrossRef]

109. Thies, F.; Wessel, M.; Benlian, A. Network effects on crowdfunding platforms: Exploring the implications of relaxing input control. Inf. Syst. J. 2018, 28, 1239-1262. [CrossRef]

110. Li, L.; Su, F.; Zhang, W.; Mao, J.Y. Digital transformation by SME entrepreneurs: A capability perspective. Inf. Syst. J. 2018, 28, 1129-1157. [CrossRef]

111. Bharadwaj, A.; El Sawy, O.A.; Pavlou, P.; Venkatraman, N. Digital business strategy: Toward a next generation of insights. MIS Q. 2013, 37, 471-482. [CrossRef]

112. Schallmo, D.; Williams, C.A.; Boardman, L. Digital Transformation of Business Models—Best Practice, Enablers, and Roadmap. Int. J. Innov. Manag. 2017, 21, 1740014. [CrossRef]

113. Sussan, F.; Acs, Z.J. The digital entrepreneurial ecosystem. Small Bus. Econ. 2017, 49, 55-73. [CrossRef]

114. Coenen, L.; Lopez, F.D. Comparing systemic approaches to innovation for sustainability and competitiveness. In Proceedings of the Submitted to DIME international conference "Innovation, Sustainability and Policy, Bordeaux, France, 11-13 September 2008; pp. 11-13.

115. Teece, D.J.; Pisano, G.; Shuen, A. Dynamic capabilities and strategic management. Strateg. Manag. J. 1997, 18, 509-533. [CrossRef]

116. Nunkoo, R. The state of research methods in tourism and hospitality. In Handbook of Research Methods for Tourism and Hospitality Management; Nunkoo, R., Ed.; Edward Elgar Publishing: Northampton, UK, 2018; pp. 3-23.

117. Langer, G. Probability Versus Non-Probability Methods. In The Palgrave Handbook of Survey Research; Vannette, D., Krosnick, J., Eds.; Palgrave Macmillan: Cham, UK, 2018; pp. 351-362.

118. Preacher, K.J.; Hayes, A.F. Asymptotic and resampling strategies for assessing and comparing indirect effects in multiple mediator models. Behav. Res. Methods 2008, 40, 879-891. [CrossRef] [PubMed]

119. Fornell, C.; Lacker, D.F. Structural equation models with unobservable variables and measurement error: Algebra and Statistics. J. Mark. Res. 1981, 18, 382-388. [CrossRef]

120. Nambisan, S. Digital entrepreneurship: Toward a digital technology perspective of entrepreneurship. Entrep. Theory Pract. 2016, 41, 1029-1055. [CrossRef]

121. Rosca, E.; Arnold, M.; Bendul, J.C. Business models for sustainable innovation-An empirical analysis of frugal products and services. J. Clean. Prod. 2017, 162, 133-145. [CrossRef]

122. Wohlfart, L.; Bünger, M.; Lang-Koetz, C.; Wagner, F. Corporate and Grassroot Frugal Innovation: A Comparison of Top-Down and Bottom-Up Strategies. Technol. Innov. Manag. Rev. 2016, 6, 5-17. [CrossRef] 
123. Levanen, T.; Venalainen, J.; Valkama, M. Interference Analysis and Performance Evaluation of 5G Flexible-TDD Based Dense Small-Cell System. In Proceedings of the 2015 IEEE 82nd Vehicular Technology Conference (VTC2015-Fall), Boston, MA, USA, 6-9 September 2015; pp. 1-7. [CrossRef]

124. Tiwari, R.; Fischer, L.; Kalogerakis, K. Frugal Innovation in Germany: A Qualitative Analysis of Potential Socio-Economic Impacts; Working Paper, No. 96; Hamburg University of Technology (TUHH), Institute for Technology and Innovation Management (TIM): Hamburg, Germany, 2017.

125. Le Bas, C. Frugal Innovation as Environmental Innovation; Electronic Working Paper Series; ESDES Research Center: Lyon, France, 2018; Volume 2, pp. 1-23. Available online: https://www.esdes.fr/wp-content/uploads/sites/12/2020/11/wp_esdes_2018_02_ le_bas.pdf (accessed on 14 May 2021).

126. Pisoni, A.; Michelini, L.; Martignoni, G. Frugal approach to innovation: State of the art and future perspectives. J. Clean. Prod. 2018, 171, 107-126. [CrossRef]

127. Shen, K.N.; Lindsay, V.; Xu, Y. Digital entrepreneurship. Inf. Syst. J. 2018, 28, 1125-1128. [CrossRef]

128. Young, A.; Selander, L.; Vaast, E. Digital organizing for social impact: Current insights and future research avenues on collective action, social movements, and digital technologies. Inf. Organ. 2019, 29, 100257. [CrossRef]

129. Rogers, E.M. Diffusion of Innovations, 5th ed.; Free Press: New York, NY, USA, 2003.

130. Rehman, N.U.; Hysa, E.; Mao, X. Does public R\&D complement or crowd-out private R\&D in pre and post economic crisis of 2008? J. Appl. Econ. 2020, 23, 349-371.

131. Suciu Marta, C.; Pelinescu, E.; Cristea, M.; Noja, G.G. Digital Transformation E the EU Labour Markets, European Conference on the Impact of Artificial Intelligence and Robotics-ECIAIR 2019; EM-Normandie Business School: Oxford, UK, 2019.

132. Neirotti, P.; Raguseo, E.; Paolucci, E. How SMEs develop ICT-based capabilities in response to their environment. J. Enterp. Inf. Manag. 2018, 31, 10-37. [CrossRef]

133. Li, T.C.; Chan, Y.E. Dynamic information technology capability: Concept definition and framework development. J. Strateg. Inf. Syst. 2019, 28, 101575. [CrossRef]

134. Bertello, A.; Ferraris, A.; Bresciani, S.; De Bernardi, P. Big data analytics (BDA) and degree of internationalization: The interplay between governance of BDA infrastructure and BDA capabilities. J. Manag. Gov. 2020. [CrossRef]

135. Henseler, J.; Ringle, C.M.; Sarstedt, M. A new criterion for evaluating discriminant validity in the modelling of structural equations based on variance. J. Acad. Brand. Sci. 2014, 43, 115-135.

136. Martínez-Navalón, J.G.; Gelashvili, V.; Debasa, F. The Impact of Restaurant Social Media on Environmental Sustainability: An Empirical Study. Sustainability 2019, 11, 6105. [CrossRef]

137. Foroudi, P.; Gupta, S.; Nazarian, A.; Duda, M. Digital technology and marketing management capability: Achieving growth in SMEs. Qual. Market. Res. An Int. J. 2017, 20, 230-246. [CrossRef]

138. Weisenfeld, U.; Reeves, J.C.; Hunck Meiswinkel, A. Technology management and collaboration profile: Virtual companies and industrial platforms in the high-tech biotechnology industries. RED Manag. 2001, 31, 91-100. 